\section{George Bornstein}

University of Michigan

\title{
Jak czytać stronę. Modernizm i materialność tekstu
}

\section{Abstract \\ How to Read a Page. Modernism and Material Textuality}

This article is a translation of the first chapter of George Bornstein's book entitled Material Modernism. The Politics of the Page (2001). The first, theoretical section of the article discusses the notion of the "bibliographic code" (all material aspects of the text) as offering important supplements to the "linguistic code" (the words of the text). The article offers analogies to Walter Benjamin's notion of the "aura" and to the concept of the "utterance," coined by the speech-act theorists. Just as Benjamin argues that the "aura" locates the work of art in time and space and the speech-act theorists contend that the "utterance" (gesture, tone etc.) functions as an important carrier of meaning, so the author sees the "bibliographic code" as an important constituent of meaning. The remaining part of the article presents exemplary readings of four sonnets, written by John Keats, Emma Lazarus, William Butler Yeats and Gwendolyn Brooks.

Słowa kluczowe: materialność tekstu, kod bibliologiczny, kod lingwistyczny, aura, znaczenie tekstu

Keywords: textual materiality, bibliographic code, linguistic code, aura, the meaning of the text 
Jeżeli Mona Lisa wisi w paryskim Luwrze, to gdzie znajduje się Król Lear ${ }^{1}$ ? Tak sformułowane pytanie, prowokując do refleksji nad istotą tekstu, uświadamia zarazem niebagatelne konsekwencje współczesnej teorii edytorstwa dla badań literackich. Nie mamy wątpliwości, że arcydzieło pędzla Leonarda da Vinci umieszczono we francuskim muzeum, a reprodukcje portretu uznajemy za mniej lub bardziej niedoskonałe kopie oryginału. W przypadku reprodukcji tekstów literackich status kopii okazuje się jednak nie tylko mniej oczywisty, lecz także całkowicie odmienny. W poszukiwaniu Króla Leara nie musimy sięgać do wydania Pied Bull Quarto czy Pierwszego Folio. Wprost przeciwnie - wersje tego arcydzieła sztuki literackiej uznawane za oryginalne mogą wszak stanowić gorsze, ułomne kopie zaginionego rękopisu lub pozbawionej błędów wersji drukowanej. Późniejsze ,kopie” mogą przewyższać pierwowzory, a krytycy z powodzeniem mogą z nich korzystać w swojej pracy. Żyjemy w czasach bezwzględnej demistyfikacji, w których właśnie tekst pozostaje często ostatnim zmistyfikowanym obiektem, skoro krytycy uznają naiwnie, że broszurowe wydania klasyki kupione w lokalnej księgarni to „faktycznie" Król Lear, Duma i uprzedzenie czy The Souls of Black Folk. Pytanie, od którego zaczęliśmy nasze rozważania, uświadamia nam, że dzieła literackie istnieją równocześnie w wielu różnych miejscach. Oznacza to, że każda badana przez nas odmiana tekstu jest zawsze tylko jednym z wielu możliwych konstruktów w świecie, który sam jest konstruktem.

Obok wyobrażenia tekstu-konstruktu drugą ważną ideą współczesnej teorii edytorstwa jest przeświadczenie o istnieniu wielu autorskich odmian jednego tekstu². Powinniśmy wiedzieć, czy istnieją (lub mogą istnieć) alternatywne wersje badanego przez nas dzieła; nie musimy jednak wykorzystywać tej wiedzy do wskazania wersji, której poświęcimy wyłączną uwagę. Przeciwnie - moglibyśmy przejąć strategię określoną przez badaczy twórczości Emily Dickinson mianem ,wyboru braku wyboru”3 i świadomie rozważać wiele wersji danego tekstu. Analizując Króla Leara, prawdopodobnie chętniej sięgnęlibyśmy do późniejszej wersji folio, doceniając przejrzysty układ prezentowanych zdarzeń, choć jednocześnie nie chcielibyśmy może pominąć słynnej sceny fikcyjnego sądu nad córkami (akt III, sc. 6), istniejącej jedynie we wcześniejszej wersji quatro. W tej sytuacji moglibyśmy zechcieć

${ }^{1}$ Nawiązuję tu do rozważań F.W. Batesona na temat Mony Lisy i Hamleta zamieszczonych w jego Essays in Critical Dissent (London 1972, s. 7-10), choć dochodzę do zdecydowanie odmiennych wniosków. Po raz pierwszy trafiłem na jego uwagi w często cytowanym artykule Jamesa McLaverty'ego The Mode of Existence of Literary Works of Art: The Case of the „Dunciad Variorum” (,Studies in Bibliography” 1984, vol. 37, s. 82-105). McLaverty parafrazował Batesona na początku swojego tekstu.

${ }^{2} \mathrm{Na}$ temat współczesnych teorii dotyczących odmian tekstu oraz ich zastosowania w odniesieniu do twórczości Yeatsa piszę w: G. Bornstein, What is the Text of a Poem by Yeats? [w:] Palimpsest. Editorial Theory in the Humanities, red. G. Bornstein, R. Williams, Ann Arbor 1993, s. 167-193.

${ }^{3}$ Zob. S. Cameron, Choosing Not Choosing: Dickinson's Fascicles, Chicago-London 1992. 
uwzględnić oba warianty, prawdopodobnie posiłkując się także współczesnym, łączącym je eklektycznym tekstem, nawet jeśli do jego powstania mogło dojść nie wcześniej, niż jakieś sto lat po śmierci Szekspira. Prawdopodobnie pragnęlibyśmy poznać liczne odmiany wierszy autorstwa takich notorycznych „poprawiaczy”, jak William Butler Yeats czy Thomas Moore, którzy hurtowo przerabiali swoje teksty. Może zainteresowałby nas fakt, że najbardziej rozpowszechniona obecnie wersja znanego eseju Martina Luthera Kinga Pilgrimage to Nonviolence (przełomowego tekstu zarówno dla mnie, jak i dla wielu przedstawicieli mojego pokolenia) pomija zawartą w oryginale krytykę marksizmu. Zarówno w tych, jak i w wielu innych przypadkach nie możemy po prostu wybrać tej lub innej wersji utworu: sami twórcy autoryzowali wiele wariantów własnego tekstu, więc my także chcemy mieć do nich dostęp. Można by zatem uznać, że dzieło literackie istnieje nie w jakiejś jednej wersji, ale we wszystkich wersjach równocześnie. Być może podczas lektury jakiejś konkretnej strony przyjdzie nam ochota, żeby zapoznać się z jej alternatywnymi wersjami, a wówczas pierwszym krokiem będzie odkrycie innych stron domagających się naszej uwagi.

Taka strategia prowadzi do trzeciej metody czytania strony proponowanej przez współczesną teorię edytorstwa: należy mieć świadomość, że tekst jest zawsze pewną konstrukcją, pamiętać o możliwości istnienia wielu alternatywnych wersji utworu, lecz także zdawać sobie sprawę, że tekst literacki składa się nie tylko ze słów (kodu lingwistycznego), lecz także ze znaczących cech jego materialnej organizacji (kodu bibliologicznego ${ }^{4}$ ), obejmujących między innymi: projekt okładki, układ tekstu na stronie czy spacje (spacing), a także inne treści zawarte w książce lub czasopiśmie, w którym ukazuje się utwór, jak również przedmowy, przypisy oraz dedykacje, wpływające na odbiór i interpretację dzieła. Te materialne cechy tekstu odpowiadają pojęciu ,aury”, którym posłużył się Walter Benjamin w słynnym eseju Dzieto sztuki w dobie reprodukcji technicznej. Benjamin - poświęcając szczególną uwagę filmowi jako następcy zarówno sztuk plastycznych, jak i druku - definiuje aurę jako kluczowy aspekt dzieła, który znika w warunkach reprodukcji technicznej:

${ }^{4}$ [Przypis redaktora numeru] Autor używa w tekście oryginalnym dwu pojęć: linguistic code oraz bibliographic code. W thumaczeniu przyjęto, odpowiednio, „kod lingwistyczny” oraz „kod bibliologiczny” (a nie - choć takie rozwiązanie mogłoby się nasuwać jako najbardziej oczywiste - „bibliograficzny”). Opowiedziano się tym samym za rozstrzygnięciem terminologicznym już na gruncie polskiego literaturoznawstwa przyjętym i uzasadnianym: termin „kod bibliologiczny” do oddania amerykańskiej kategorii tekstologicznej zaproponował Łukasz Cybulski w artykule Krytyka tekstu i teoria dzieła. Jerome McGann wobec anglo-amerykańskiej tradycji edytorstwa naukowego, „Teksty Drugie” 2014, nr 2, s. 39. Warto dodać na marginesie, że artykuł Łukasza Cybulskiego (podobnie jak artykuł Pawła Bema Nowa bibliologia - nowa krytyka. Paradoksy relacji, „Teksty Drugie” 2015, nr 3) znakomicie prezentuje historię amerykańskiego edytorstwa ostatnich dekad, tym samym czyniąc bardziej czytelnymi konteksty historyczne, do których odnosi się w swoim studium George Bornstein. 
Nawet przy najdoskonalszej reprodukcji nie ma mowy o jednym, niepowtarzalnym związku dzieła sztuki z miejscem i czasem jego istnienia. [...] Więź oryginału z miejscem i czasem jego istnienia składa się na pojęcie autentyczności. [...] Okoliczności, w jakich może się znaleźć produkt reprodukcji technicznej, mogą zresztą nie naruszać egzystencji dzieła sztuki, niemniej pozbawiają pierwotnego znaczenia nierozerwalny związek z miejscem i czasem jego istnienia. [...] Zatraca się tutaj coś, co się streszcza w pojęciu aury, słowem: to, co obumiera w epoce technicznej reprodukcji dzieła sztuki, to jego aura ${ }^{5}$.

Benjaminowska ,aura” odnosi się zatem przede wszystkim do obecności dzieła sztuki w czasie i przestrzeni (to znaczy w historii) i okazuje się szczególnie zagrożona w epoce reprodukcji technicznej. Choć Benjamin dostrzegał „obumieranie” aury w dobie reprodukcji technicznej, można by skorygować jego przekonanie, zauważając, że w przypadku literatury mechaniczne powielanie tekstu powołuje do istnienia egzemplarze posiadające własną aurę, a tym, co „obumiera” w wyniku reprodukcji, jest aura wcześniejszych wydań, zwłaszcza jeśli tożsamość ,dzieła” rozpatruje się tylko w odniesieniu do tworzących je słów. Aura ujawnia się jednak także poprzez materialne cechy tekstu, dlatego jego wcześniejsze materialne wcielenia posiadają aurę, która umieszcza dzieło w czasie i przestrzeni oraz nadaje mu zarówno autentyczność, jak i przygodny charakter. Usunięcie jej prowadzi do usunięcia ikonicznych właściwości strony, na której tekst został wydrukowany, a w konsekwencji - odarcia go z istotnych aspektów jego znaczenia.

Echa benjaminowskiego pojęcia aury pobrzmiewają w koncepcji kodu bibliologicznego proponowanej przez współczesnych teoretyków edytorstwa, m.in. przez Jerome'a McGanna. W zbiorze esejów zatytułowanym The Textual Condition McGann, wprowadzając pojęcie kodu bibliologicznego, krytykuje zasadę eklektycznego edytowania tekstu i opowiada się za uwzględnieniem w szerszym zakresie kontekstu społecznego. Czyniąc rozróżnienie między słowną zawartością dzieła, czyli „kodem lingwistycznym”, a jego materialnymi właściwościami, czyli „kodem bibliologicznym”, McGann zwraca uwagę na

[...] symboliczny i znaczeniowy wymiar materialnego medium, poprzez które (a raczej w którym) ucieleśnia się tekst językowy [...]. Nośnikiem znaczenia jest $\mathrm{w}$ równym stopniu kod lingwistyczny, jak i bibliologiczny [...]. W wyniku transmisji tekstu [...] znaczenie dzieła staje się wytworem o coraz bardziej zbiorowym i społecznym charakterze [...] Ze stanowiskiem tym współbrzmi przekonanie, że żadne postępowanie edytorskie - żaden pojedynczy „tekst” konkretnego dzieła nie może zostać uznane za „właściwe” [...]. Należy zrozumieć, że w skład archiwum wchodzą nie tylko oryginalne rękopisy, egzemplarze zawierające korekty

${ }^{5}$ W. Benjamin, Dzieło sztuki $w$ dobie reprodukcji technicznej, przeł. J. Sikorski [w:] idem, Anioł historii. Eseje, szkice, fragmenty, wybór i oprac. H. Orłowski, Poznań 1996, s. 204-207. 
i redakcje, lecz także kolejne tekstowe formy, jakie przybiera utwór w historii swego bytowania ${ }^{6}$.

Elementami składającymi się na kod bibliologiczny mogą być zarówno układ strony, opracowanie graficzne książki, rodzaj użytego atramentu i papieru, zastosowany krój pisma, jak i dane dotyczące wydawcy, nakładu, ceny czy grupy odbiorców - które Donald Francis McKenzie mógłby nazwać „,socjologią tekstu"7. McGann, prezentując swoje stanowisko w książce zatytułowanej The Textual Condition, kwestionuje koncepcje edytorskiego eklektyzmu autorstwa Grega-Bowersa, odwołujące się do ostatecznej intencji autora, ja jednak chciałbym podkreślić zgodność pojęcia „kodu bibliologicznego” z Benjaminowskim pojęciem aury: oba terminy wskazują bowiem na „obecność dzieła w czasie i w przestrzeni”. Kolejne reprezentacje tekstu, zwłaszcza jeśli skupiają się wyłącznie na kodzie lingwistycznym, przywodzą na myśl zjawisko zanikania aury. Przeważnie uwalniają one tekst od kontekstu, w którym powstał, i umieszczają go w naszym czasie oraz przestrzeni raczej jako obiekt estetyczny niż historyczny.

Trzecim pojęciem pomocnym przy zgłębianiu problematyki materialnego aspektu tekstu jest pojęcie wypowiedzi zaczerpnięte z teorii aktów mowy. Już Peter Shillingsburg w ważnym artykule Text as Matter, Concept and Action przekonywał o znaczeniu teorii aktów mowy dla rozważań na temat tekstu i jego edycji, twierdząc, że na tekst składa się jego warstwa materialna (jego kształt fizyczny), pojęciowa (odnosząca się przede wszystkim do idei tkwiących w umysłach autorów i edytorów) oraz działania podejmowane przez czytelników lub słuchaczy. W krótkim referacie Refining the Social Contract, wygłoszonym na konferencji zorganizowanej przez Society for Textual Scholarship w 1995 roku i opublikowanym w rozszerzonej wersji w książce Resisting Text, Shillingsburg rozwija swoje stanowisko:

Zarówno proces pisania, jak i czytania jest bardziej zrozumiały, gdy mamy świadomość różnicy między skutkami tych działań a celami, dla których je podejmujemy. John Searle podkreśla to rozróżnienie, wyjaśniając różnicę między zdaniem a wypowiedzeniem. Zdanie jest strukturą formalną, składającą się ze słów i relacji między nimi. Zdanie może być zapisane jako seria słów; zdania są powtarzalne. Natomiast wypowiedzenie to jednostkowe wykorzystanie zdania do przekazania zamierzonej treści. To samo zdanie, wypowiedziane w różnych okolicznościach, zmienia swoje znaczenie. [...] W tekście pisanym utrwalone zostają w ich dosłownym brzmieniu zdania, a nie wypowiedzenia. W tekstach pisanych wypowiedzenie zostaje zredukowane do zdania. W mowie pojawiają się dodatkowe elementy po-

${ }^{6}$ J.J. McGann, The Textual Condition, Princeton 1991, s. 56-62. Bardziej szczegółowe omówienie poglądów McGanna dotyczących kodu bibliologicznego znajdzie czytelnik w moim artykule: G. Bornstein, Beyond Words: Reviewing Jerome J. McGann, , The Textual Condition” and „Black Riders: The Visible Language of Modernism”, „Text” 1995, vol. 8, s. 387-396.

${ }^{7}$ D.F. McKenzie, Bibliography and the Sociology of Texts, London 1986. 
zatekstowe, takie jak ton głosu, gestykulacja, mowa ciała, czas i miejsce wypowiedzi oraz rzeczywisty odbiorca. W przypadku pisma wskaźniki pozatekstowe, choć nie tak oczywiste jak w żywej mowie, także istnieją i tworzą kod bibliologiczny, a więc środki wykorzystywane przez pisarzy, wydawców i czytelników w celu przekształcenia zdania w wypowiedź ${ }^{8}$.

McGann stworzył swoją koncepcję po części w odpowiedzi na edytorski eklektyzm Grega Bowersa, natomiast Shillingsburg rozwinął swoją, aby odeprzeć skrajne stanowisko, jakie prezentował konstruktywizm społeczny. Podkreślam tutaj podobieństwo teorii aktów mowy do dwóch wcześniej przywołanych koncepcji: aury i kodu bibliologicznego. W takim ujęciu kod bibliologiczny jest tekstową formą, jaką przyjmują akty mowy. Materialne właściwości tekstu odpowiadają materialnym właściwościom aktu mowy, które sprawiają, że zdanie zmienia się w wypowiedzenie. Te same cechy przyczyniają się do powstania aury tekstu.

Twierdzę, że zarówno McGann i Shillingsburg, jak i ja doszliśmy do podobnych wniosków, rozczarowani tradycyjnymi teoriami edytorskimi stosowanymi do dziewiętnasto- i dwudziestowiecznych autorów, takich jak Byron, William M. Thackeray czy Yeats, których edycje krytyczne przygotowywaliśmy, lecz także takich, jak William Blake, Emily Dickinson oraz Ezra Pound, których twórczości nie mieliśmy okazji opracowywać. Krótko mówiąc, tradycyjna anglo-amerykańska praktyka edytorska $\mathrm{z}$ trudem radzi sobie ze złożonymi kwestiami tekstowymi, z którymi muszą się mierzyć edytorzy dzieł z ostatnich dwóch wieków, gdzie problemem jest raczej nadmiar materiałów i świadectw niż ich niedostatek. Widziana w takiej perspektywie anglo-amerykańska „kopytekstowa” metoda edytorskiego eklektyzmu ${ }^{9}$ staje się tylko jednym $z$ wielu, a nie jedynym sposobem postępowania edytorskiego. Metoda ta zdaje się przy tym pomijać ważne elementy znaczenia wytwarzanego przez tekst. Elementy te, niezależnie od tego, czy porównamy je do aury, kodu bibliologicznego czy aktu mowy, pozwalają na uhistorycznienie dzieła. Natomiast główne założenia - zarówno wyrafinowanego eklektyzmu, jak i naiwnego redukcjonizmu - stawiają znak równości między „tekstem” a słowami czy kodem lingwistycznym, doprowadzając do odhistorycznienia dzieła.

Przywołane tu pomysły teoretyczne chciałbym zilustrować na przykładzie lektur czterech sonetów napisanych przez twórców wywodzących się

${ }^{8}$ P. Shillingsburg, Text as Matter, Concept and Action, „Studies in Bibliography” 1991, vol. 44, s. 31-82; idem, Resisting Texts, Ann Arbor 1997, s. 105-106 i 155.

${ }^{9}$ [Przyp. redaktora numeru] W oryginale: „Anglo-American copy-text eclecting editing”. Termin „copy-text”, jedno z centralnych pojęć tradycyjnej amerykańskiej teorii i praktyki edytorskiej, oznacza - najogólniej mówiąc - idealną podstawę wydania. Omówienie problemów związanych $\mathrm{z}$ tym pojęciem znaleźć można w przywoływanym już w przypisie 4 artykule Łukasza Cybulskiego. Tam również zaproponowano - użyty w naszym thumaczeniu - polski termin „metoda kopytekstowa”. 
$\mathrm{z}$ różnych środowisk społecznych i tworzących $\mathrm{w}$ różnych okresach $\mathrm{w}$ ciągu ostatnich dwóch stuleci. Zdecydowałem się na sonet bynajmniej nie dlatego, by uprzywilejować poezję lub obłaskawić duchy przedstawicieli Nowej Krytyki - Cleantha Brooksa czy Austina Warrena - snujące się dzisiaj niczym zjawy po korytarzach akademii. Uczyniłem to z trzech głównych powodów. Po pierwsze, sonet stanowi krótką, przystępną ilustrację zasad, które odnoszą się do wszystkich form tekstowych. Po drugie, wybrałem sonety, które często omawiamy na zajęciach; wszystkie na przykład znajdują się w najnowszym wydaniu The Norton Anthology of Poetry. Wreszcie po trzecie, sonety w powszechnej opinii uchodzą za jedną z najbardziej „estetycznych” form literackich. Poza kilkoma ewidentnie politycznymi utworami autorstwa Miltona czy Wordswortha, sonety wydają się ludziom tak dalekie od zaangażowania politycznego, jak to tylko w przypadku literatury możliwe. A jednak, jak się przekonamy, materialny wymiar tekstu analizowanych sonetów wpisuje je w konteksty polityczne zarówno ich, jak i naszych czasów. Zajmiemy się zatem sonetami angielskiego poety romantycznego Johna Keatsa, dziewiętnastowiecznej amerykańskiej pisarki żydowskiego pochodzenia Emmy Lazarus, irlandzkiego modernisty W.B. Yeatsa i współczesnej autorki afroamerykańskiej Gwendolyn Brooks.

Rozważania rozpoczniemy od analizy czterech materialnych postaci tekstu sonetu Keatsa On first looking into Chapman's Homer, wiersza bez wątpienia kanonicznego, nawet $\mathrm{w}$ czasach tak niechętnych wszelkiemu kanonowi. Porównamy z sobą rękopis, pierwodruk w czasopiśmie „The Examiner”, pierwsze wydanie książkowe w tomie wierszy Keatsa Poems z 1817 roku oraz współczesny przedruk w The Norton Anthology of Poetry (wydanie czwarte). Materialna organizacja tekstu za każdym razem uwypukla inny aspekt wiersza, wymuszając odmienny tryb lektury. Rękopis (il. 1) na przykład kieruje naszą uwagę ku elementom charakterystycznym dla formy sonetowej, co czyni z wiersza przede wszystkim przedmiot estetyczny. Jest coś rozbrajającego w geście Keatsa, który, aby sprostać wymagającemu petrarkiańskiemu układowi rymów, dorysował na prawym marginesie strony linie łączące kolejne rymowane wyrazy

Much have I travell'd in the Realms of Gold And many godly States, and Kingdoms seen;

Round many Western islands have I been, Which Bards in fealty to Apollo hold.

Oft of one wide expanse had I been told, Which deep brow'd Homer ruled as his Demesne;

Yet could I never judge what Men could mean, Till I heard Chapman speak out loud, and bold.

Then felt I like some Watcher of the Skies When a new Planet swims into his Ken, Or like stout Cortez, when with wond'ring eyes He star'd at the Pacific, and all his Men 


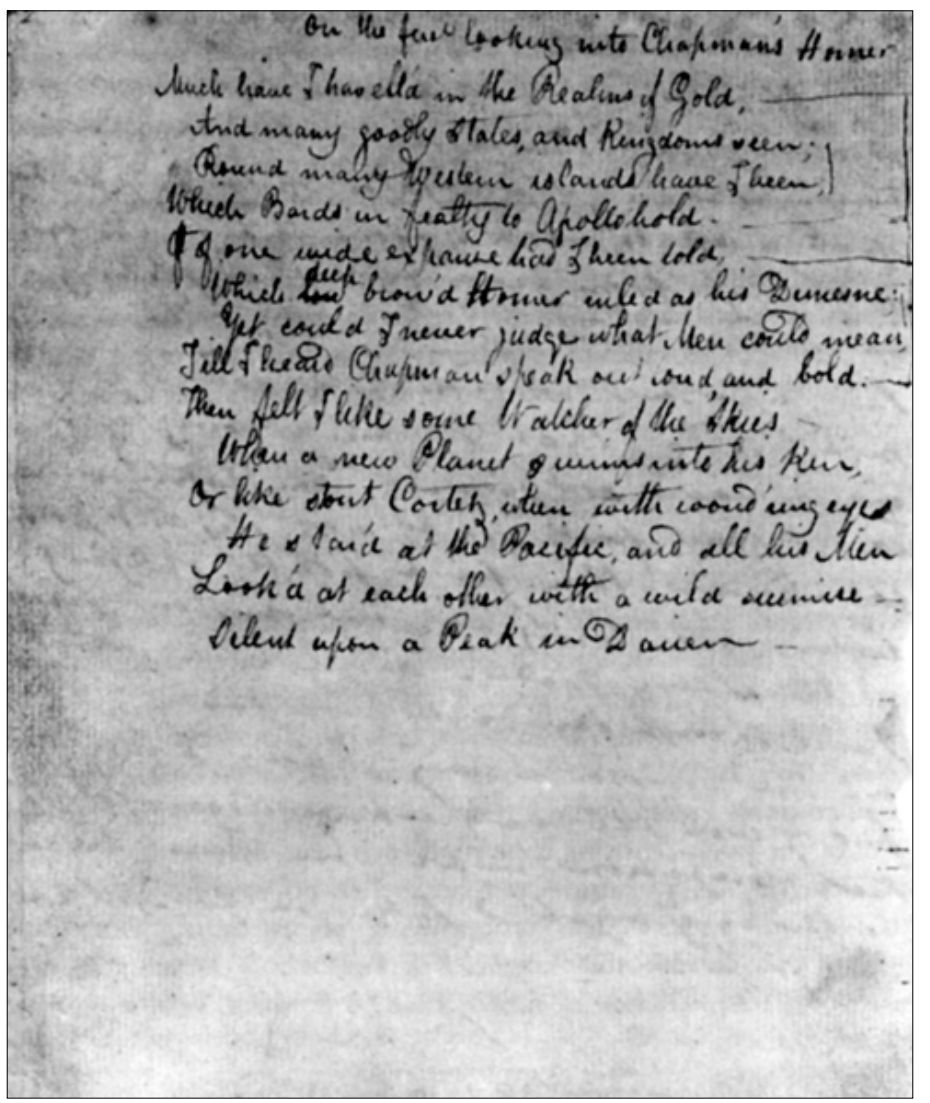

Il. 1. J. Keats, On First Looking into Chapman's Homer, rękopis

Look'd at each other with a wild surmise Silent upon a Peak in Darien ${ }^{10}$.

${ }^{10}$ Oryginalny rękopis znajduje się w Houghton Library na Harvardzie. Zob. J. Keats, Poetry Manuscripts at Harvard: A Fascimile Edition, red. J. Stillinger, Cambridge, Mass., 1990, s. 12. Polski przekład wiersza w thumaczeniu Stanisława Barańczaka:

\section{Na pierwsze zapoznanie się z Homerem w przekładzie Chapmana}

Złotych krain w wędrówkach zwiedziłem już wiele;

Mnóstwo widziałem świetnych księstw, poznałem mrowie

Zachodnich wysp, gdzie wielcy królują bardowie -

Apollina lennicy i wierni czciciele.

I słyszałem, że ląd gdzieś rozległy się ściele,

Gdzie włada mędrzec Homer; ale czym jest zdrowie

Czystej pogody owych stron - ani w połowie

Nie przeczułem. Dopiero gdy dźwięcznie i śmiele

Przemówił Chapman - naglem zamarł, jak widokiem

Niespodzianej planety olśniony astronom; 


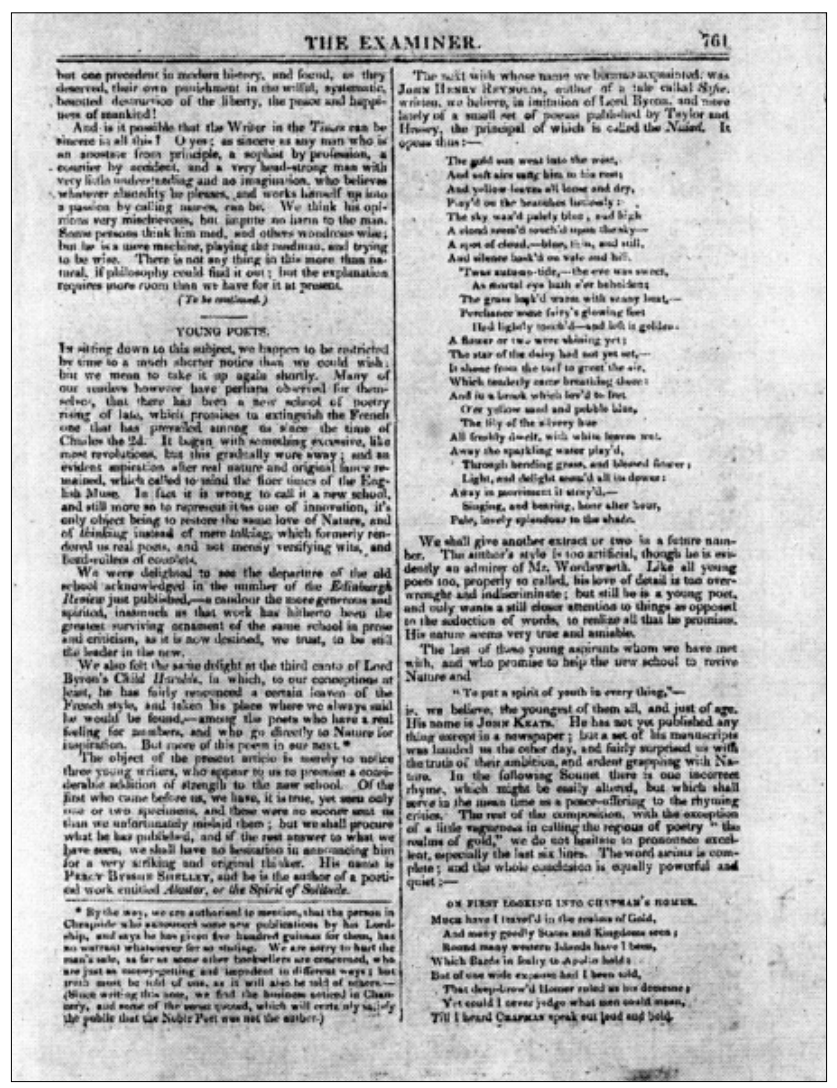

Il. 2. J. Keats, On First Looking into Chapman's Homer, druk w czasopiśmie „The Examiner”

Rękopis w stosunku do wersji drukowanych zawiera także znaczące rozbieżności na poziomie kodu lingwistycznego; na przykład brzmienie siódmego wersu: „Yet could I never judge what men could mean” różni się od późniejszego „Yet could I breathe its pure serene”, a „wond'ring eyes” w wersie zostaną zastąpione przez ,eagle eses”. Lektura rękopisu nie tylko uwypukla elementy formalne sonetu, lecz także potęguje naszą świadomość istnienia empirycznego autora wiersza, Johna Keatsa.

Z kolei kodowanie bibliologiczne tekstu w przedruku zamieszczonym w czasopiśmie „The Examiner” akcentuje polityczny i społeczny wydźwięk utworu (il. 2) ${ }^{11}$. Postępowe czasopismo o profilu politycznym i literackim wydawane

Albo jak śmiałek Cortez na wzgórzu wysokiem

Panamskiego przesmyku, gdy jego legionom

Podziw odebrał mowę - a on orlim okiem

Mknął ponad Pacyfikiem ku nieznanym stronom.

11 „The Examiner: A Weekly Paper on Politics, Literature, Music, and Fine Arts” (London) $\mathrm{nr}$ 466, 1 December 1816, s. 761-762. 
przez Leigha Hunta, przyjaciela, a także mentora Keatsa, promowało wszelkie ówczesne przejawy liberalizmu, a sam Hunt trafił do więzienia za publikację artykułów sprzeciwiających się karom cielesnym wymierzanym żołnierzom brytyjskim w czasie wojen napoleońskich. W interesującym nas numerze periodyku znajdziemy artykuł o Napoleonie, a także opis masowej demonstracji, podczas której domagano się żywności dla biednych, reportaż o dramacie ludzi, których dziś określilibyśmy mianem miejskiej podklasy, oraz materiały nawołujące do wprowadzenia reform społecznych. Co wynika z faktu, że utwór ukazał się po raz pierwszy drukiem w takim miejscu? By móc prawidłowo odpowiedzieć na to pytanie, musimy pamiętać, że On First Looking... to pierwszy utwór Keatsa sygnowany jego nazwiskiem, a więc w zasadzie jego poetycki debiut. Jak mógł on współgrać z politycznym i społecznym charakterem pisma „The Examiner”? Pamiętajmy, że Alexander Pope, najsłynniejszy wieszcz wcześniejszego stulecia, dorobił się sporych pieniędzy dzięki tłumaczeniu Homera. Warto zestawić ten fakt z pierwszą informacją, którą dzieli się z czytelnikami Keats przy okazji swojego debiutu. Stwierdza on mianowicie, że nie włada greką, przyznając się tym samym w ostentacyjny sposób do swojego pochodzenia społecznego, które uniemożliwiło mu zdobycie wykształcenia typowego dla ówczesnej klasy wyższej, a nawet średniej. Keats w sonecie obwieszcza, że nie jest arystokratą, co nie przeszkadza mu jednak czuć się poetą. W ten sposób jego utwór współbrzmi $\mathrm{z}$ liberalną orientacją pisma, realizując $\mathrm{w}$ sferze poetyckiej to samo demokratyczne zaangażowanie, które „The Examiner” głosił w przestrzeni politycznej. W podobny zresztą sposób współcześni Keatsa postrzegali twórczość romantyczną. Hazlitt zauważał na przykład, że poezja Wordswortha

[...] uczestniczy w ruchu rewolucyjnym naszych czasów i ulega jego namiętnej sile: współczesne zmiany polityczne stały się modelem, zgodnie z którym [Wordsworth] tworzył i przeprowadzał swoje eksperymenty poetyckie [...]. Jego Muza opowiada się po stronie równości ${ }^{12}$.

A więc już sama obecność wiersza On first looking... w „The Examiner” podkreśla jego związki z romantyczną polityką rewolucyjną, tym bardziej że pojawia się on w artykule, w którym Keats łączony jest z Shelleyem. Tak właśnie należałoby zatem czytać wiersz zamieszczony na łamach pisma „,The Examiner".

Trzeci kontekst, tom wierszy Keatsa Poems z roku 1817, przynosi dalszą, choć nieco bardziej powściągliwą, kontynuację wcześniejszych akcentów politycznych - choćby wtedy, gdy autor zaznacza, że jest twórcą wystarczająco utalentowanym i istotnym, by zasłużyć na publikację zbioru składającego się $\mathrm{w}$ całości $\mathrm{z}$ jego własnych wierszy ${ }^{13}$. Ten gest stanowi moment przełomowy w karierze Keatsa i świadczy o jego rosnącej reputacji. Wygląd strony tytułowej (il. 3) podkreśla wątki polityczne: uwagę zwraca znaczące słowo „liberty”

${ }^{12}$ Cyt. za: M.H. Abrams, English Romanticism: The Spirit of the Age [w:] Romanticism Reconsidered, red. N. Frye, New York-London 1963, s. 27.

13 J. Keats, Poems, London 1817. 


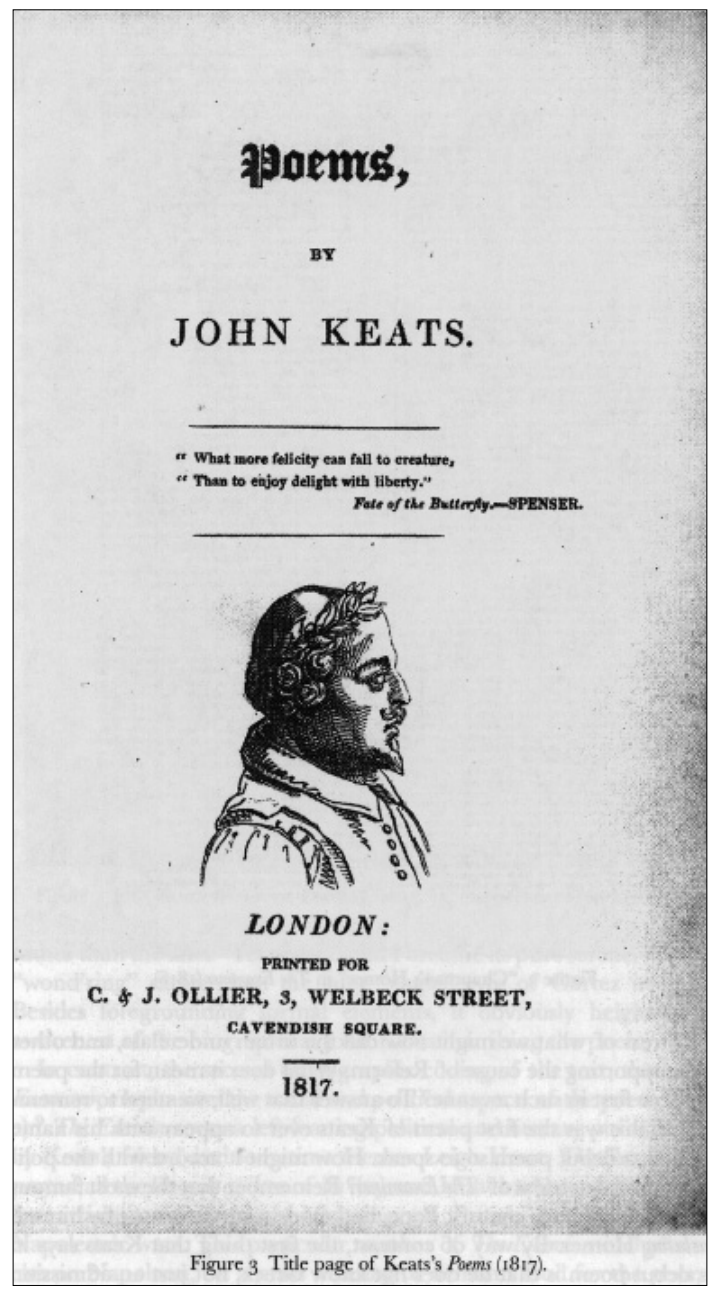

Il. 3. J. Keats, Poems (1817), strona tytułowa

w motcie zaczerpniętym z Edmunda Spensera (,What more felicity can fall to creature, / Than to enjoy delight with liberty"), a także wybór wydawcy. Jako pierwsi dzieła Percy'ego Shelleya i innych pisarzy liberalnych udostępnili publiczności bracia J. i C. Ollierowie, (zwłaszcza drugi z nich słynął ze swoich radykalnych poglądów). Polityczną wymowę ma także dedykacja dla samego Hunta: człowieka z temperamentem politycznym, w odniesieniu do którego zarówno słowo „biedny”, użyte w ostatniej linijce, jak i określenie „człowiek twojego pokroju” nabierają szczególnego znaczenia. Spoglądając na spis treści, dostrzegamy, że On first looking into Chapman's Homer jest teraz częścią cyklu sonetów zawierających wyraźne polityczne odniesienia: jak trzeci z kolei utwór Written on the Day That Mr. Leigh Hunt Left Prison 


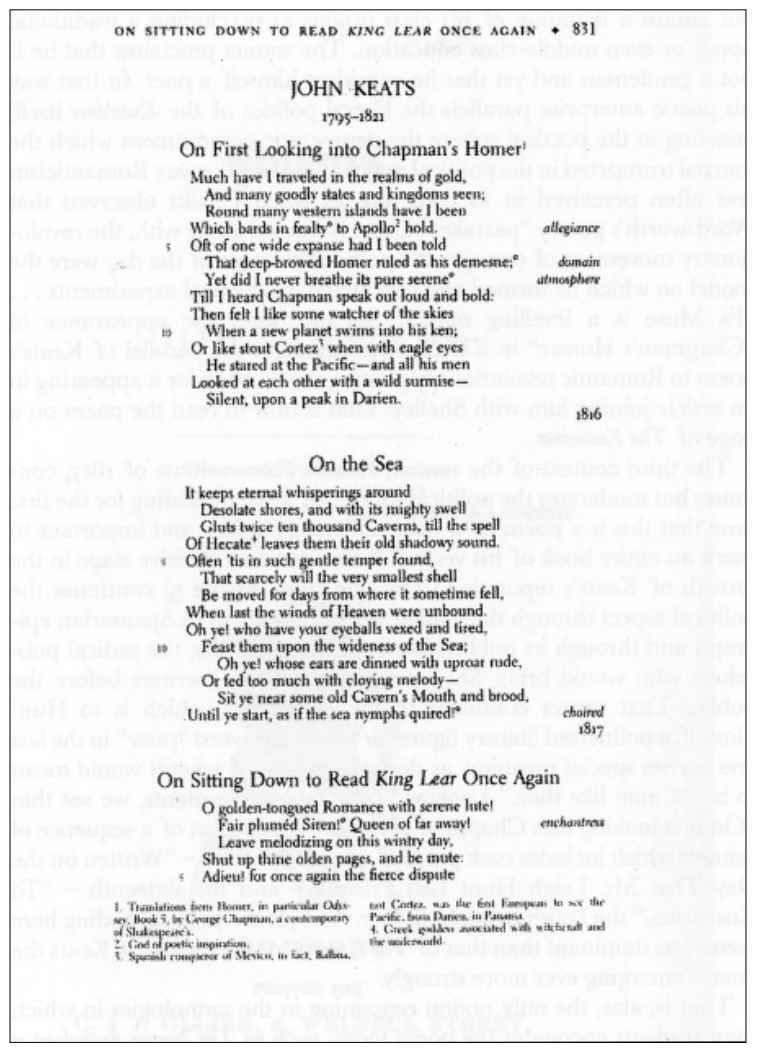

Il. 4. J. Keats, On First Looking into Chapman's Homer, druk w The Norton Anthology of Poetry

czy szesnasty - To Kosciusko - poświęcony polskiemu bojownikowi o wolność. Mimo to obraz Keatsa poety dominuje tutaj wyraźnie nad politycznym kontekstem obecnym silniej w „The Examiner”.

Poetycka autokreacja to niestety jedyne co da się zauważyć podczas lektury tego wiersza w antologiach, takich jak The Norton Anthology of Poetry (il. $4)^{14}$, za sprawą których większość studentów styka się dzisiaj z utworem Keatsa. W antologii Nortona kod lingwistyczny wiersza zostaje całkowicie odarty z treści zawartych w kodzie bibliologicznym. Aspekty społeczne, polityczne i osobiste, jakie zawierał ów kod, zredukowano do podania daty pierwodruku (1816), która powie prawdopodobnie niewiele przeciętnemu studentowi drugiego roku. Taka redukcja służy uwypukleniu estetycznego aspektu dzieła, jako elementu kluczowego, a przywołanie daty wydaje się służyć umieszczeniu utworu Keatsa w historycznej perspektywie rozwoju angielskiej poezji.

${ }^{14}$ The Norton Anthology of Poetry, fourth edition, red. M. Ferguson, M.J. Salter, J. Stallworthy, New York 1996, s. 831. 


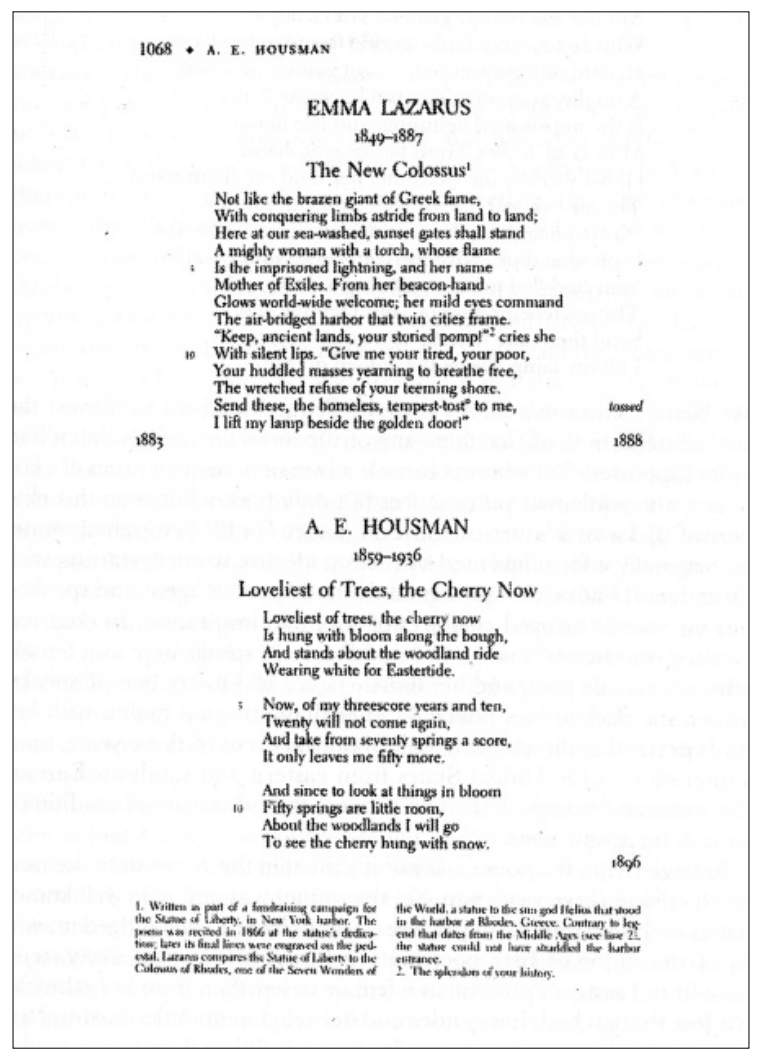

I1. 5. E. Lazarus, The New Colossus, druk w The Norton Anthology of Poetry

W tym sensie antologia czyni z wierszami to, co muzeum czyni z dziełami sztuki: wyrywa je z politycznego i społecznego kontekstu - niezależnie od tego, czy tworzy go kościół, pałac, ratusz czy jakaś inna siła - i umieszcza w zdekontekstualizowanej przestrzeni, która uwypukla wyłącznie jego cechy estetyczne i stylistyczne. W takim ujęciu ,ideologia antologii” nie oznacza wyboru utworów reprezentujących jakieś ideologiczne punkty widzenia, lecz ukazuje raczej samą antologię jako odhistorycznione pole, które przesłania społeczne podłoże składających się na nią wierszy. W każdym z czterech analizowanych przez nas materialnych kontekstów poszczególne teksty jawią się jako przedmioty skonstruowane, a nie magiczne przezroczyste soczewki pozwalające nam ujrzeć „prawdziwego” Keatsa, Szekspira czy Dickinson.

Dotychczasowe rozważania na temat materialnych aspektów tekstu wzbogaci analiza The New Colossus (il. 5), słynnego sonetu Emmy Lazarus:

Not like the brazen giant of Greek fame,

With conquering limbs astride from land to land;

Here at sea-washed, sunset gates shall stand 
A mighty woman with a torch, whose flame Is the imprisoned lighting, and her name Mother of Exiles. From her beacon-hand Glows world-wide welcome; her mild eyes command The air-bridged harbor that twin cities frame. 'Keep ancient lands, your storied pomp!' cires she With silent lips. 'Give me your tired, your poor, Your huddled masses yearning to breathe free, The wretched refuse of your teeming shore.

Send these, the homeless, tempest-tost to me, I lift my lamp beside the golden door!'15

Lazarus, podobnie jak Keats, wykorzystuje formę sonetu włoskiego, aby zakwestionować zarówno samą tę formę, jak i wspierany przez nią porządek społeczny. O ile jednak Keats skupiał się na kwestiach klasowych (nie jest arystokratą, a jednak para się nie tylko poezją, ale też jej najbardziej elitarną i kunsztowną formą), o tyle Lazarus koncentruje się na problematyce genderowej. Sonet włoski stanowił formę ekspresji wymyśloną przez mężczyzn w celu idealizacji obrazu kobiety. Począwszy od Sonetów do Laury, przedstawiał mężczyznę-poetę jako podmiot sprawczy i ja mówiące, a kobietę jako przedmiot miłości i źródło inspiracji. Tymczasem Lazarus (która zresztą tłumaczyła Petrarkę) wypowiada się w wierszu jako poetka, a także oddaje głos kobiecej inkarnacji Wolności; co więcej, powodują nią nie tyle względy uczuciowe, ile polityczne. Jej słowa odnoszą się bezpośrednio do ważnych wydarzeń politycznych tamtego czasu: masowej migracji z Europy południowej i wschodniej do Stanów Zjednoczonych. Materialne cechy utworu w zaskakujący sposób wzmacniają jego subwersywny potencjał.

Zacznijmy od tego, że sonet Emmy Lazarus zamieszczono dopiero w czwartym wydaniu antologii Nortona z 1996 roku: powodem wykluczenia

${ }^{15}$ The Norton Anthology of Poetry, s. 1068. Wiersz w polskim przekładzie Wiktora J. Darasza:

\section{Nowy Kolos Rodyjski}

Nie niczym grecki gigant ze spiżu odlany, Ze stopami po obu stronach morskiej toni, Młoda, mocna kobieta, trzymająca w dłoni Pochodnię, stanie dumnie u portowej bramy. A światło jej pochodni to piorun schwytany, Ucieczka Uciśnionych jej imię, bo chroni. Głosi ona gościnę wszystkim, co pogoni Uszli i przybywają do krain nieznanych. „Stare kraje, swą dawną zachowajcie chwałę" Wykrzykuje bez przerwy niemymi wargami„Dajcie mi tylko swoich biednych thumy całe, Obejmę ich gościnnie mymi ramionami. Przyślijcie mi bezdomnych gromady niemałe, Dla nich podnoszę lampę nad portu wodami”. 
go z wcześniejszych trzech edycji zbioru był prawdopodobnie fakt, iż utwór uchodził za tak powszechnie znany, że aż niegodny włączenia do kanonu wysokiej poezji. Decyzja o ostatecznym uwzględnieniu go w antologii wiązała się zapewne z pozycją literacką Lazarus, a nie jej płcią czy żydowskim pochodzeniem, choć bez wątpienia religia i płeć odegrały pewną rolę w owych czasach, tak wyczulonych na kwestie tożsamości. Również jawnie polityczny temat utworu, który mógł budzić zastrzeżenia redaktorów wychowanych w duchu Nowej Krytyki, wydał się zapewne bardziej atrakcyjny redaktorom antologii w latach dziewięćdziesiątych XX wieku. Świadczą o tym towarzyszące utworowi przypisy, które wskazują (niestety nieprecyzyjnie) na polityczny kontekst wiersza i nowatorską rewizję pierwotnego znaczenia tytułowego posągu.

W przypisie do wiersza $\mathrm{w}$ czwartym wydaniu antologii podano błędną informację, jakoby wiersz został napisany z okazji kwesty mającej pokryć koszty wzniesienia Statuy Wolności. W rzeczywistości celem kampanii było zebranie środków na budowę masywnego cokołu, na którym spoczęła statua ufundowana przez naród francuski ${ }^{16}$. Utwór Lazarus odczytano na gali otwarcia wystawy Art Loan Exhibition in Aid of the Bartholdi Pedestal Fund for the Statue of Liberty w 1883 roku, towarzyszącej zbiórce środków przeznaczonych na sfinansowanie postumentu, a nie (jak podano w antologii) z okazji odsłonięcia samej Statuy Wolności. Uroczystość odsłonięcia posągu odbyła się w roku 1886, a nie, jak podaje The Norton Anthology, w 1866, a więc krótko po nadejściu fali masowej imigracji do Stanów Zjednoczonych. W 1866 roku, gdy naród amerykański żył jeszcze wydarzeniami niedawno zakończonej wojny secesyjnej, idea Wolności, wyrażona fundacją pomnika, miałaby zupełnie inne znaczenie polityczne, odnoszące się raczej do świeżo wyzwolonych niewolników niż do nowo przybyłych imigrantów. Co więcej, komentarz w antologii pomija znaczącą rewizję znaczenia posągu dokonaną przez Emmę Lazarus. Pierwotnie grupa umiarkowanych republikańskich intelektualistów zgromadzonych wokół Edouarda-Renégo Lefebvre'a de Laboulaye'a nazwała statuę mianem „Wolności Rozświetlającej Świat”. Ich intencją było wzniesienie największego pomnika w Ameryce, który byłby dowodem na przejęcie przez Stany Zjednoczone francuskich ideałów Wolności i umożliwiałby ich ponowne przeszczepienie na grunt Francji czasów II Cesarstwa. Działania te stanowiły element, zakończonej ostatecznie sukcesem, kampanii zmierzającej do ustanowienia III Republiki, która przetrwała aż do roku 1940. Autor posągu, rzeźbiarz Frédéric Auguste Bartholdi, w podobny sposób wyjaśniał symbolikę Statuy Wolności. Miała ona nieść przesłanie Europie, odzwierciedlając uczestnictwo Nowego Świata w ogólnoświatowym ruchu politycznym. Tymczasem Lazarus dokonała reinterpretacji Wolności jako typowo amerykańskiej bogini („Matki Wygnańców”) witającej uciekinierów z uciskającej swoich obywateli Europy w nowym, wolnym świecie. Właśnie taka symbolika statuy miała się utrwalić w przyszłości. Dokonane przez Lazarus odwró-

${ }^{16}$ Wszystkie informacje czerpię z książek Marvina Trachtenberga The Statue of Liberty (New York 1986) oraz Oscara Handlina The Statue of Liberty (New York 1977). 
22

George Bornstein

The hew Colorens.

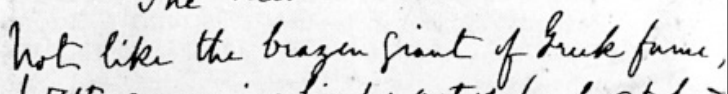

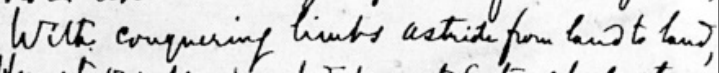

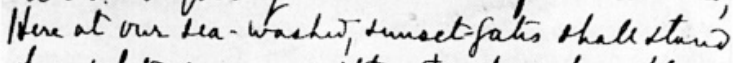
At mights worman wilt a trest, whose flane

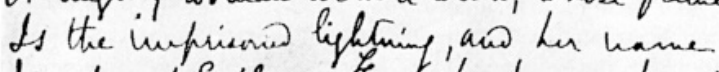
horther of Exiles. Trenc her taeon. hand. Glowr wonld. wide beterme, hu miled ayes eommence

the air. hidged hartor that twin-cities forme.

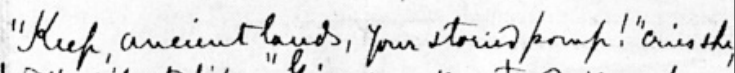

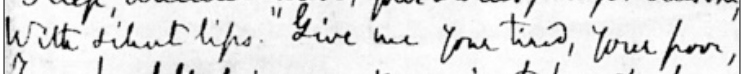
Tour hudded messes yearing to treacte free, The writehed refure of Your teeming thene, Send these, the hom lase, tenferet torst to me, I lift my launf beaide the freden dorn!"

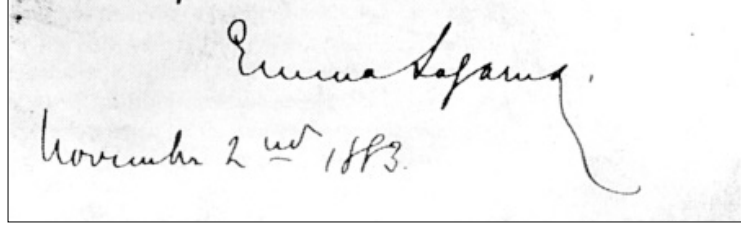

Il. 6. E. Lazarus, The New Colossus, rękopis

cenie porządku w przestrzeni polityki historycznej dopełnia podobny zabieg zastosowany w odniesieniu do płci i przypisanych jej ról społecznych.

Najważniejszą kwestią związaną z oryginalnym materialnym kształtem tekstu wiersza jest fakt, że autorka pisała go nie z myślą o publikacji, lecz z zamiarem wystawienia rękopisu na aukcji podczas zbiórki pieniędzy na postument (il. 6). W przeciwieństwie do Keatsa, dla którego rękopis stanowił jedynie wstęp do publikacji wersji drukowanej, Lazarus, podobnie jak Dickinson, pisała ze świadomością, że to rękopis był pierwotną formą upublicznienia wiersza. W przeciwieństwie jednak do Dickinson autorka The New Colossus nie pisała z myślą o przeznaczeniu rękopisu wyłącznie na użytek swój i wąskiego grona zaprzyjaźnionych osób. Przeciwnie. Decydując się na napisanie sonetu z zamiarem wystawienia rękopisu na aukcji, od początku chciała uczynić go materialnym obiektem kultu, swoistym fetyszem, a kwota za jego nabycie miała zasilić konto funduszu na rzecz budowy cokołu, dzięki czemu to Statua Wolności (a nie The New Colossus) miała stać się obiektem goszczącym na stałe w przestrzeni publicznej. Dlatego też, mimo początkowego entu- 


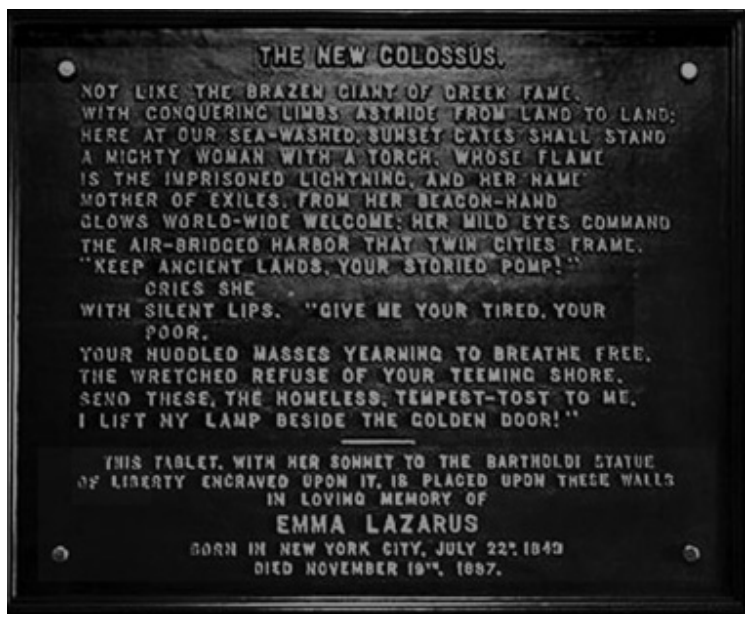

Il. 7. E. Lazarus, The New Colossus, tablica z brązu, Statua Wolności

zjazmu towarzyszącego prezentacji sonetu (James Russell Lowell na przykład napisał do autorki, że jej wiersz stał się raison d'être monumentu), wiersz popadł w zapomnienie na piętnaście lat. Ukazał się tylko na łamach jednej gazety (,The New York World”), a poetka nie przedrukowała go w żadnej z książek poetyckich wydanych w owym krótkim okresie, jaki pozostał jej jeszcze do śmierci, mimo iż uwzględniła go w rękopisowym zbiorze swoich wierszy ${ }^{17}$.

Okres zapomnienia dobiega końca w roku 1903, kiedy to Georgina Schuyler, przyjaciółka Emmy Lazarus, doprowadza do umieszczenia tablicy z brązu z zapisanym na niej sonetem wewnątrz cokołu (il. 7), a nie jak głosi nieszczęsny przypis w antologii Nortona, ,do wygrawerowania go na cokole”, na którym spoczywa Statua Wolności. I w tym przypadku materialność tekstu okazuje się znacząca: utwór zapisany na tablicy przytwierdzonej do postumentu przestaje być po prostu sonetem poświęconym pomnikowi, lecz staje się jego integralną częścią. Przypomina to liczne przykłady paratekstów w literaturze modernistycznej - wstępy i przypisy autorstwa Yeatsa, Pounda, Woolf czy Eliota - które w założeniu miały wpływać na kształt interpretacji, a ostatecznie stały się częścią komentowanego tekstu. Utwór zapisano w całości przy użyciu kapitalików, które podkreślają jego ,pomnikowy” charakter, podobnie jak umieszczona pod nim inskrypcja, przywołująca zarówno twórcę pomnika, jak i autorkę wiersza:

TABLICE TE, Z WYGRAWEROWANYM NA NIEJ SONETEM OPIEWAJĄCYM STATUE, WOLNOŚCI WYKONANĄ PRZEZ BARTHOLDIEGO, WMUROWANO NA TYM MIEJSCU DLA UPAMIĘTNIENIA EMMY LAZARUS, URODZONEJ W NOWYM JORKU 22 LIPCA 1849 ROKU, ZMARŁEJ 19 LISTOPADA 1887 ROKU.

${ }_{17}$ Zob. B.R. Young, Emma Lazarus in Her World, Philadelphia 1995, rozdz. 1. 
Tablicę przytwierdzono do postumentu na trwałe, tak jak na trwałe zapisał się w świadomości kolejnych pokoleń Amerykanów rewizjonistyczny sens wiersza Emmy Lazarus.

Przywołując inskrypcję umieszczoną na płycie z brązu, nie sposób nie wspomnieć o granitowej tablicy umieszczonej w terminalu przylotów międzynarodowych na nowojorskim lotnisku im. Johna Fitzgeralda Kennedy’ego, zawierającej tekst, który moglibyśmy nazwać politycznie poprawną wersją interesującego nas sonetu. W dzisiejszych czasach, gdy imigranci znacznie częściej przybywają do Stanów Zjednoczonych drogą powietrzną niż wodną, ktoś wpadł na ciekawy pomysł, aby wiersz Emmy Lazarus witał przybyszów w lotniskowej hali przylotów, tak jak wcześniej Statua Wolności witała ich w nowojorskim porcie. Opuszczono jednak istotny fragment utworu, mimo iż zmiana ta zaburzyła rytm i schemat rymów w sonecie. Wielkimi, złotymi zgłoskami zapisano:

Give me your tired, your poor,

Your huddled masses yearning to breathe free, $[\ldots]$

Send these, the homeless, tempest-tost to me,

I lift my lamp beside the golden door!

Pominięty wers brzmi: „The wretched refuse of your teeming shore” („Nędzne odpadki z twoich thumnie zaludnionych brzegów”). Władze uznały prawdopodobnie, że ten fragment mógłby znieważać przybyszów, a być może nawet drastycznie obniżyć ich poczucie wartości. Podobnie jak w większości tego typu przypadków, ingerencja cenzury przyniosła skutek odwrotny do zamierzonego. Każdemu, kto zna oryginał wiersza, ocenzurowana wersja jawi się przede wszystkim jako nadzwyczaj protekcjonalny akt wymierzony w tych, których chciano chronić. Warto w tym kontekście przytoczyć fragment felietonu Stephena Jay Goulda, znanego przyrodnika, który w „The New York Times" z 1995 roku wyraził swoje oburzenie, pisząc:

Polityka językowa zwycięża zdrowy rozsądek. Czy cenzorzy słyszeli kiedykolwiek o metaforze? A może doszli do wniosku, że Lazarus opisuje stosunek rządzących do potencjalnych emigrantów w jakimś obcym kraju? Lepiej dmuchać na zimne i zniszczyć poezję $^{18}$.

A co z drukowanymi wersjami utworu, funkcjonującego pierwotnie w wersji rękopiśmiennej, następnie wygłoszonego na wernisażu wystawy, a w końcu umieszczonego na tablicy pamiątkowej przytwierdzonej do postumentu? Do rozpoznawalności wiersza przyczyniła się przede wszystkim niezliczona ilość przedruków na pocztówkach, w broszurach, antologiach i książkach historycznych, jednak w kontekście dorobku poetyckiego Lazarus najważniejsze strony z interesującym nas sonetem znajdziemy w dwutomowym zbiorze utworów poetyckich Poems of Emma Lazarus (Boston 1889) wydanym po śmierci autorki oraz

${ }^{18}$ S.J. Gould, No More „Wretched Refuse”, „The New York Times”, Wednesday, 7 June 1995. 


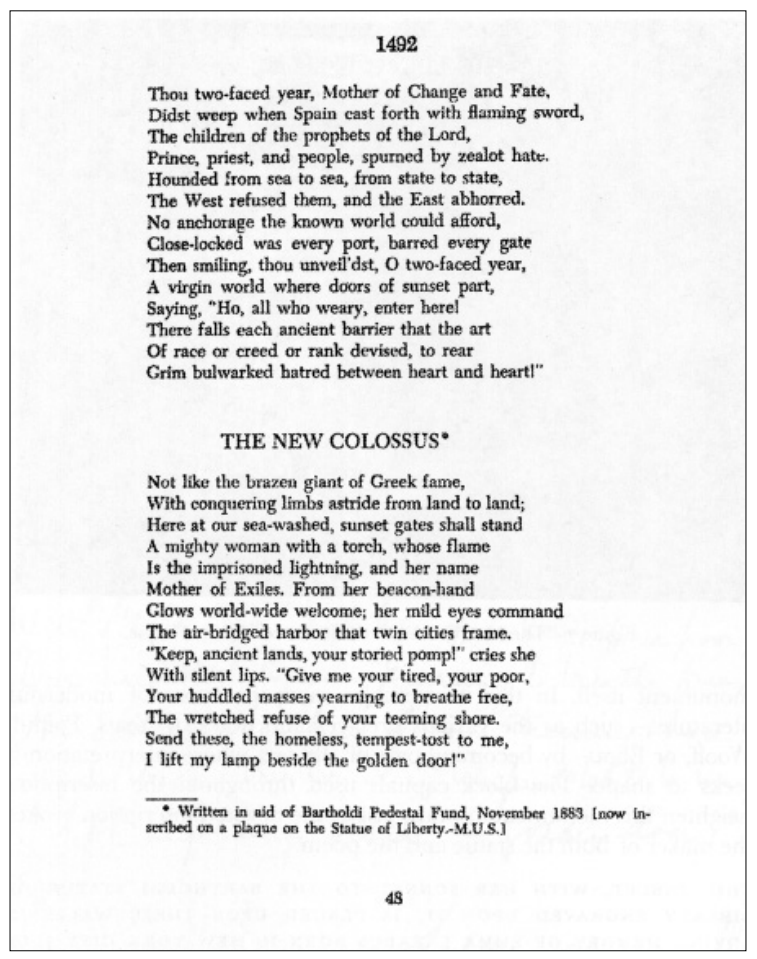

Il. 8. E. Lazarus, The New Colossus, druk w tomie Emma Lazarus: Selections from her Poetry and Prose, edycja Schappesa

w wyborze poezji i prozy Emma Lazarus: Selections from her Poetry and Prose pod redakcją Morrisa Schappesa, opublikowanym pierwotnie przez International Workers Order (IWO) - (organizację związkową działającą pod egidą Komunistycznej Partii Stanów Zjednoczonych [CPUSA]), a następnie przez Jewish Publication Society (najstarszego wydawcę hebrajskich książek w Ameryce) ${ }^{19}$. Długa droga, jaką edycja przygotowana przez Schappesa przebyła od wydania przez Cooperative Book League amerykańsko-żydowskiej sekcji IWO po reedycję Jewish Publication Society, przywodzi na myśl skomplikowane losy Żydów i robotników w amerykańskiej historii. Materialny wymiar tekstu The New Colossus rekontekstualizuje wymowę wiersza, umieszczając go w kontekście historii Żydów i dodając w ten sposób dodatkowy wymiar do dziejów jego recepcji i interpretacji (il. 8). Schappes umieszcza wiersz między innym sonetem włoskim, łączącym rok 1492 nie tylko z odkryciem Nowego Świata, lecz także z wygnaniem

19 Emma Lazarus: Selections from Her Poetry and Prose, red. M.U. Schappes, New York 1944. Kolejne poprawione i rozszerzone wydania ukazywały się w Nowym Jorku najpierw nakładem Book League, Jewish People's Fraternal Order of the International Workers Order (w 1947 r.), a następnie nakładem Emma Lazarus Federation of Jewish Women's Clubs w roku 1967 i 1978. Reprodukowana strona pochodzi z wydania z 1967 r. 
Żydów z Hiszpanii, a stylizowanym na sonet utworem opiewającym „ostatniego żydowskiego wojownika” - Szymona Bar Kochbę, przywódcę powstania Żydów w Imperium Rzymskim. Dzięki takiemu sąsiedztwu szczególnymi bohaterami The New Colossus stają się Żydzi, ponieważ to między innymi oni współtworzyli wielką falę emigracji napływającą do Stanów Zjednoczonych w okresie między pogromem kiszyniowskim w 1881 roku a wprowadzeniem restrykcyjnej polityki imigracyjnej w USA na początku lat dwudziestych XX wieku. Układ utworów w tomie Schappesa podkreśla ów szczególny udział ludności żydowskiej wśród „uciemiężonych mas pragnących oddechu...”, a także żydowskie pochodzenie autorki wiersza, nawet jeśli wywodziła się ona z zamożnej i ustatkowanej rodziny Żydów sefardyjskich, a nie spośród cierpiących niedostatek aszkenazyjskich imigrantów. Krótki przypis, którym opatrzono wydanie Schappesa, określa też okoliczności powstania i lokalizację inskrypcji dokładniej niż rozbudowany przypis w The Norton Anthology...

Możemy teraz powrócić do strony z sonetem w The Norton Anthology... bogatsi o kilka informacji. Nie chodzi mi o piętnowanie autorów, chcę tylko pokazać na tym przykładzie charakterystyczne cechy nawet najznakomitszych antologii skierowanych do wąskiego grona odbiorców. Po pierwsze, przypisy, mające przybliżać kontekst historyczny, zawierają często błędy, niekiedy bardzo poważne. Po drugie, w przypadku The New Collosus zadrukowana strona $\mathrm{w}$ antologii nie daje wyobrażenia o wcześniejszych formach funkcjonowania utworu: najpierw jako fetyszyzowanego rękopisu, będącego przedmiotem licytacji, następnie jako utworu wygłoszonego publicznie, a w końcu jako powszechnie dostępnej inskrypcji na płycie przytwierdzonej do postumentu Statuy Wolności lub tej umieszczonej na lotnisku. To przypomina nam, że większość dzieł poetyckich funkcjonowała pierwotnie nie w wersji drukowanej, ale w formie rękopiśmiennej lub ustnej, i że zadrukowana strona jest zawsze przekładem, który zawiera w sobie element konstrukcji oraz interpretacji. Wcześniejsze materialne okoliczności istnienia utworu przypominają nam także o jego pierwotnym politycznym znaczeniu, które trudno dostrzec wyłącznie na podstawie kodu lingwistycznego, a które staje się oczywiste dzięki znajomości kodu bibliologicznego lub materialnego.

Dotychczas rozważałem przypadki, w których leksykalny kształt utworu nie ulegał zmianie. Pokazywałem, jak zmieniające się kody bibliologiczne mogą modyfikować znaczenie wierszy, nawet jeśli ich kod lingwistyczny pozostaje niezmieniony. Sonet W.B. Yeatsa Leda and the Swan (Leda i łabędz) jest przykładem utworu, w którym obserwujemy zmiany tekstualne zarówno na poziomie werbalnym, jak i materialnym. Poniżej zamieszczam pierwszą strofę sonetu w takim kształcie, w jakim ukazała się w pierwszych trzech wydaniach: w amerykańskim czasopiśmie „The Dial”, irlandzkim „To-morrow” i w tomie wierszy Yeatsa zatytułowanym The Cat and The Moon (Kot i księ$\dot{z} y c)$ z 1924 roku (il. 9) ${ }^{20}$.

${ }^{20}$ W.B. Yeats, The Cat and the Moon and Certain Poems, Dublin 1924. 


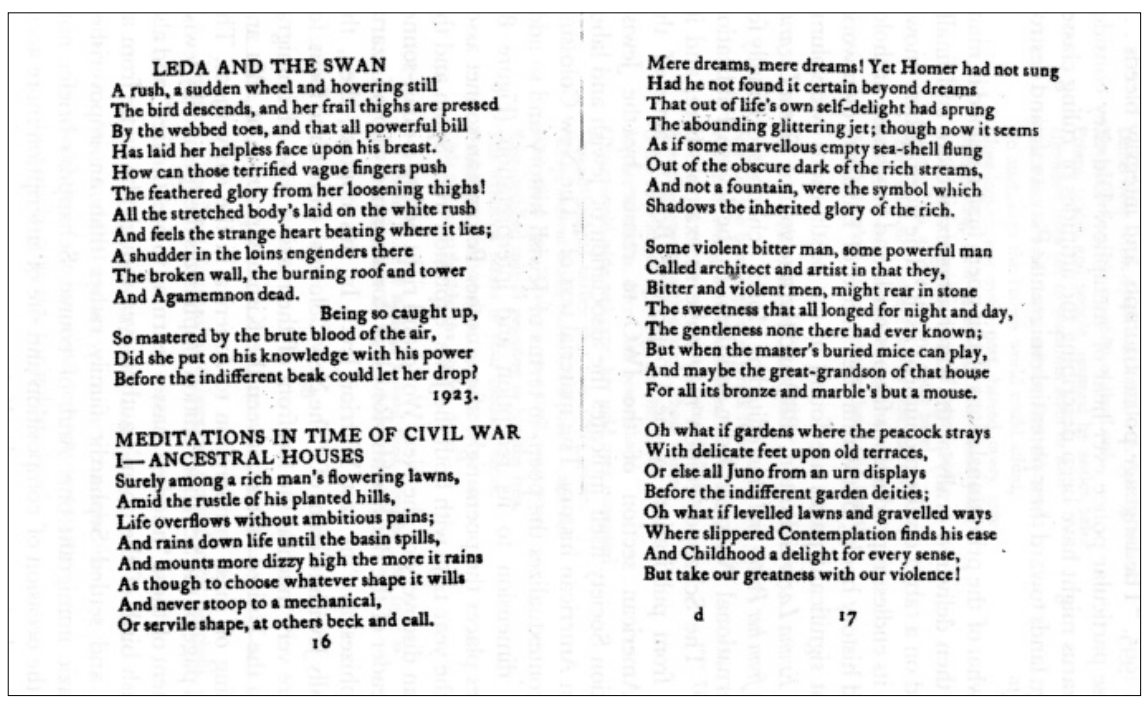

Il. 9. W.B. Yeats, Leda and the Swan, druk w tomie The Cat and The Moon

A rush, a sudden wheel, and hovering still

The bird descends, and her frail thighs are pressed

By the webbed toes, and that all-powerful bill

Has laid her helpless face upon his breast ${ }^{21}$.

Rok później, w rozprawie zatytułowanej A Vision (Wizja), sonet ukazał się w innej, najczęściej dziś przedrukowywanej wersji. Autor zmienił pierwszą zwrotkę, nadając jej bardziej dramatyczny wydźwięk:

A sudden blow: the great wings beating still

Above the staggering girl, her tights caressed

By the dark webs, her nape caught in his bill,

He holds her helpless breast upon his breast ${ }^{22}$.

Podkreślenie przemocy, z jaką Zeus zbliża się do Ledy, jest szczególnie wyraźne w pierwszym wersie utworu, a zwłaszcza w pierwszych słowach zmienionej wersji - „A sudden blow” - („Nagły cios”), oraz w takich zwrotach, jak: „the great wings beating” (,wielkie bijące skrzydła”) czy ,the staggering girl” („słaniająca się dziewczyna”). Podkreślenie tej brutalności,

21 „The Dial”, June 1924. Jedyna różnica, jaka pojawia się w następnych dwóch wydaniach, to brak przecinka po słowie ,wheel” w pierwszym wersie w tomie Cat and the Moon.

22 W.B. Yeats, A Vision, London 1925, s. 179. W przekładzie J. Pietraszkiewicza:

Nagły cios. Trzepot wielki: jeszcze skrzydła oba

Nad dziewczyną, co słania się - już płetwy ślisko

Głaszczą uda - już kark jej schwycił w kleszcze dzioba.

Trzyma ją, pierś bezbronną swoją piersią ściska. 
która zmienia niewinny flirt w gwałt, było największą innowacją wniesioną przez Yeatsa do tradycyjnych sposobów przedstawiania relacji Zeusa i Ledy. Wcześniej, na obrazach Coreggia, Leonarda, Tintoretta czy Michała Anioła, scena przedstawiała miłosne igraszki spokojnej Ledy - panującej nad sytuacją i zwykle większej od łabędzia. Tradycyjne przedstawienia tej sceny nie wynikały jedynie z przyjęcia męskiej perspektywy patrzenia. Podobne ujęcie odnajdziemy w wierszu Leda autorstwa Hildy Doolittle, która dzięki znakomitemu, klasycznemu wykształceniu dobrze znała tradycyjne sposoby przedstawiania tej mitologicznej sceny. W końcowych wersach poematu, wydanego zaledwie kilka lat przed utworem Yeatsa, poetka tak oto interpretuje mit:

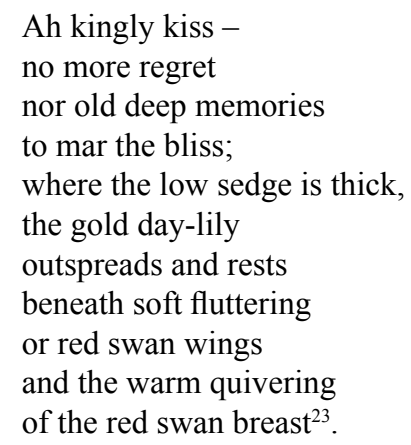

Takie określenia, jak „kingly kiss” („królewski pocałunek”) czy „warm quivering” (,ciepłe drżenie”), bogata kolorystyka utrzymana w tonacji czerwieni i złota oraz niespieszny rytm wiersza wskazują na bardziej tradycyjną interpretację tej sceny jako przyjemnej gry miłosnej. Yeats, zamiast podążyć tym tropem, wybiera odmienne przedstawienie. Istotną funkcję pełni forma wybrana przez autora: sonet, powstały jako środek idealizacji kobiety, służy tu przedstawieniu bardziej brutalnej wersji historii Ledy. Brutalność wyrażona zmianami w treści pierwszej czterowersowej strofy współgra z tematami podejmowanymi w tomie The Tower (1928), w którym wiersz ostatecznie znalazł swoje miejsce.

Utwór Leda and the Swan, podobnie jak większość wierszy Yeatsa powstałych w XX wieku, ukazał się wcześniej w tomie wydanym przez wydawnictwo Cuala Press znane ze swoich feministycznych sympatii. Naszą analizę możemy rozpocząć w tym przypadku od metryczki - wydrukowanej na czerwono, więc tym bardziej rzucającej się w oczy. Podobnie jak wszystkie inne metryczki wydawnictwa Cuala, zawiera ona informacje dotyczące książki, takie jak wysokość nakładu, nazwisko redaktora, rodzaj użytego papieru, datę wydania. Znajdziemy tam również następującą informację:

W tym miejscu kończy się tom Williama Butlera Yeatsa The Cat and the Moon and Certain Poems. Z inicjatywy Elizabeth Corbet Yeats wydrukowano go na irlandz-

${ }^{23}$ H.D., Collected Poems 1912-1944, red. L.L. Martz, New York 1983, s. 121. 
kim papierze i wydano w nakładzie 500 egzemplarzy w wydawnictwie Cuala Press mieszczącym się przy Merrion Square w Dublinie. Ukończono pierwszego maja roku tysiąc dziewięćset dwudziestego czwartego.

Nota zdradza linię programową wydawnictwa wspierającego emancypację zarówno kobiet, jak i narodu irlandzkiego. Początkowo dom wydawniczy był częścią Dun Emer Industries, przedsiębiorstwa założonego przez Evelyn Gleeson z pomocą Susan (Lily), a zwłaszcza Elizabeth (Lolly) Yeats; wsparcia technicznego udzielał im Emery Walker, współpracownik Williama Morrisa, a opiekę literacką sprawował W.B. Yeats. Wydawnictwo miało zapewniać młodym Irlandkom środki utrzymania pozwalające im na zachowanie niezależności ${ }^{24}$. Zatrudniano w nim wyłącznie kobiety zarówno na stanowiskach kierowniczych, jak i robotniczych, a zarządzanie firmą zmierzało w stronę kolektywnych form podejmowania decyzji, zwłaszcza po tym, jak wydawnictwo odłączyło się od Dun Emer Industries i przyjęło nazwę Cuala Press. Pierwotna nazwa, Dun Emer, wskazywała na feministyczną i narodową orientację przedsięwzięcia (Dun w języku gaelickim oznacza fort, a Emer to imię legendarnej królowej Irlandii, żony wojownika Cuchulaina). Obie te kwestie pojawiają się w metryczce, która zwraca uwagę na kierownicze stanowisko kobiety (Elizabeth Yeats) i użycie irlandzkiego papieru w wydawnictwie świadomym swojej narodowej tożsamości. To, że poemat ukazał się w Cuala Press, nie oznacza, rzecz jasna, iż jego wydźwięk był jednoznacznie zdeterminowany przez feministyczne i narodowe sympatie wydawnictwa, świadczy jednak o tym, że autor chciał wydać swoje dzieło właśnie w takim miejscu i że pomysł ten spotkał się $\mathrm{z}$ akceptacją grupy kobiet o silnie nacjonalistycznych poglądach, które zapewne nie opublikowałyby tekstu, gdyby uznały go za sprzeczny $\mathrm{z}$ wyznawanymi przez siebie ideami. Podobne stanowisko zajęłaby zapewne Lady Gregory, wieloletnia przyjaciółka i sojuszniczka Yeatsa, której poeta zadedykował książkę.

Materialna forma wiersza, znajdującego się pomiędzy otwierającą tom, rozbudowaną dedykacją dla Lady Gregory i zamykającą go metryczką autorstwa Elizabeth Yeats, dodatkowo uwypukla konteksty polityczne i historyczne (il. 9). Utwór wydrukowano czcionką typu Caslon, jedyną, jaką dysponowato wydawnictwo, a Yeats w przypisie dodanym do tego wydania, przybliżył genezę poematu. Warto zwrócić uwagę na fakt, że notę sformatowano pod względem wielkości i kroju czcionki tak, jak tekst główny, jakby chcąc przez to wskazać na równorzędność obu elementów:

Napisałem Ledę $i$ łabędzia w odpowiedzi na prośbę redaktora pewnego czasopisma politycznego. Pomyślałem sobie: „Indywidualistyczny, demagogiczny ruch polityczny zainicjowany przez Hobbesa i rozpowszechniony dzięki encyklopedystom i Rewolucji Francuskiej wyjałowił glebę do tego stopnia, że nie będzie ona

${ }^{24}$ Najlepsze opracowanie historii wydawnictwa Cuala Press zawiera praca Liama Millera The Dun Emer Later the Cuala Press, Dublin 1973. Zob. też W.M. Murphy, Family Secrets: William Butler Yeats and his Relatives, Syracuse 1995 i G. Lewis, The Yeats Sisters and the Cuala, Dublin 1994. 
w stanie wydać plonów przez kolejne wieki”. A potem: „Jedyne, co może nas teraz czekać, to ruch lub narodziny zesłane nam z góry, poprzedzone gwałtownym zwiastowaniem”. Wykorzystałem historię Ledy i łabędzia, żeby przedstawić tę myśl za pomocą metafory... ${ }^{25}$

W tomie The Cat and the Moon kluczowy kontekst stanowi sytuacja polityczna Irlandii, na co wskazuje następujący bezpośrednio po wierszu Leda and the Swan długi poemat Meditations in Time of Civil War (Rozmyślania podczas wojny domowej). Takie sąsiedztwo zwraca uwagę czytelnika na fakt, że utwór ukazał się dwa lata po utworzeniu Wolnego Państwa Irlandzkiego, gdy Yeats pełnił urząd senatora, i rok po zakończeniu krwawej wojny domowej, która wybuchła tuż po ogłoszeniu niepodległości przez Irlandię.

Materialny kształt strony sugeruje jeszcze szersze pole historycznych odniesień. Podobnie jak pozostałe książki wydane w Cuala Press, tom wierszy Yeatsa zaprojektowano tak, że na rozkładówkach górny margines jest stosunkowo wąski, a zewnętrzne marginesy na stronie są nieco szersze od wewnętrznych $^{26}$. Taki układ typograficzny przywodzi na myśl projekty książek Williama Morrisa, mentora W.B. Yeatsa i współpracownika Emery Walker, która uczyła Elizabeth Corbet Yeats sztuki typograficznej. Projekt miał budzić skojarzenie z wyglądem średniowiecznych rękopisów i w ten sposób wyrażać sprzeciw wobec kapitalistycznych metod produkcji w wiktoriańskiej Anglii. Podobny wydźwięk miało praktykowane przez Cuala Press zastępowanie czarnego tuszu czerwonym. Typografia książki stanowiła krytykę warunków produkcji kapitalistycznej przełomu XIX i XX wieku i odwoływała się do alternatywnych modeli społecznych, na przykład tak jak w tym przypadku - modelu średniowiecznego. Materialność strony rozszerza zatem polityczne przesłanie wiersza o wymiar związany z rozwojem historycznym, który współbrzmi z tematem wiersza: wiersz przywołuje koniec jednej epoki i zapowiada początek następnej, tak jak projekt graficzny odwołuje się do epok innych niż współczesna. Zwieńczeniem tego sposobu myślenia są rozważania Yeatsa z pogranicza filozofii mistycznej, historii i psychologii zatytułowane A Vision (Wizja) i opublikowane po raz pierwszy w 1925 roku. Sonet sąsiaduje tam na rozkładówce ze schematycznym diagramem przedstawiającym słynne, projektowane przez Yeatsa, przenikające się wzajemnie stożki, które dzielą historię na dwa tysiącletnie cykle (il. 10) ${ }^{27}$. Liczby na diagramie znajdujące się poza nawiasami reprezentują daty roczne, natomiast liczby w nawiasach odnoszą się do równie słynnego podziału typów psychologicznych przeprowadzonego przez Yeatsa na podstawie 28 faz księżyca. Ezra Pound określił ten drugi system mianem ,wybitnie zbzikowanego" (i kto to mówi!). Ponieważ

${ }^{25}$ The Cat and the Moon, s. 37.

${ }^{26} \mathrm{Na}$ temat znaczenia projektów typograficznych i graficznych w Dun Emer i Cuala Press, zwłaszcza w odniesieniu do koncepcji Morrisa, zob. J.J. McGann, Black Riders: The Visible Language of Modernism, Princeton 1993, i D. Holdeman, Much Labouring: the Texts and Authors of Yeats's First Modernist Books, Ann Arbor 1997.

${ }^{27}$ A Vision, op.cit., s. 178. 


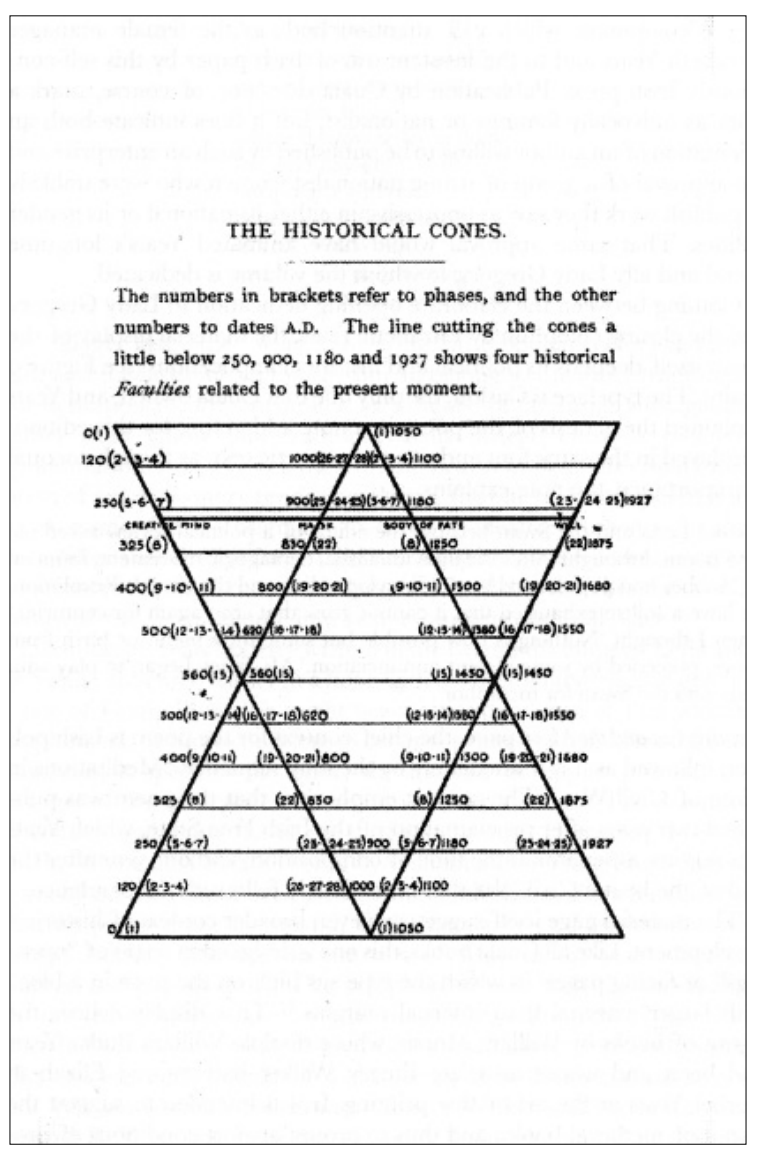

Il. 10. W.B. Yeats, A Vision, diagram sąsiadujący z tekstem wiersza Leda and the Swan

nie mam zamiaru brnąć w ezoteryczne intuicje Yeatsa, zaznaczam jedynie, że diagram wpisuje wiersz w całą historię zachodniego świata, i przechodzę do analizy sonetu w kształcie, który uzyskał w późniejszych antologiach poezji. Aby nie ograniczać się tylko do jednego przykładu, wybrałem tym razem nie antologię Nortona, lecz inny, wydany współcześnie, prestiżowy wybór angielskiej poezji The Columbia Anthology of British Poetry ${ }^{28}$. Także w tym przypadku pominięto analizowane przez nas elementy kodu bibliologicznego i lingwistycznego. W antologii nie znajdziemy również żadnego odsyłającego do nich przypisu. Wiersz opublikowano bowiem bez przypisów, a dwa akapity wprowadzenia do części poświęconej twórczości Yeatsa zawierają jedynie krótki komentarz biograficzny: ,Yeats, prezentując w swoich utworach śmia-

${ }^{28}$ The Columbia Anthology of British Poetry, red. C. Woodring, J. Shapiro, New York 1995, s. 714-715. 
łość i piękno Ledy i Heleny Trojańskiej, za pomocą uniwersalnego mitu dokonuje charakterystyki Maude [sic!] Gonne, irlandzkiej sufrażystki i bojowniczki, swojej nieodwzajemnionej miłości” (s. 712). Nie ma śladu po politycznych czy historycznych znaczeniach ujawniających się poprzez materialność zadrukowanej strony we wcześniejszych wydaniach, nie ma też wzmianki o tym, że czterowiersz otwierający utwór został opublikowany trzykrotnie, za każdym razem $\mathrm{w}$ innym brzmieniu. Wspominam o tych brakach nie po to, aby formułować zarzuty pod adresem Columbia Anthology, wydanej starannie przez dwóch wybitnych badaczy. Chcę raczej pokazać, że tego rodzaju pominięcia są nieodłączną cechą wszystkich antologii, które ograniczają się do reprodukowania tekstów w ich kształcie lingwistycznym i dążą do zredukowania wszelkich edytorskich komplikacji.

Ostatni przykład, który chciałbym poddać analizie, pochodzi z twórczości Gwendolyn Brooks, współczesnej poetki afroamerykańskiej. To jej słynny sonet my dreams, my works, must wait till after hell (il. 11):
I hold my honey and I store my bread In little jars and cabinets of my will. I label clearly, and each latch and lid I bid, Be firm till I return from hell. I am very hungry. I am incomplete. And none can tell when I may dine again. No man can give me any word but Wait, The punny light. I keep eyes pointed in; Hoping that, when the devil days of my hurt Drag out to their last dregs and I resume On such legs as are left me, in such heart As I can manage, remember to go home, My taste will not have turned insensitive To honey and bread old purity could love ${ }^{29}$.

Utwór, zamieszczony w antologii jako osobny sonet, zazwyczaj jawi się studentom jako zagadkowy. Wydaje się zapisem doświadczeń kogoś, kto już uległ lub wkrótce ulegnie psychologicznej traumie i kto wyobraża przyszłość pozwalającą mu wydobyć się z owej traumy. Typowe dla kultury Afroamerykanów zwroty językowe (,we real cool”) oraz konkretne nawiązania (na przykład do Medgara Eversa, działacza ruchu praw obywatelskich, zastrzelonego w 1963 roku) obecne w wierszach sąsiadujących w antologii z my dreams, my works... pozwalają się domyślać, że także w tym utworze kwestie rasowe odgrywają istotną rolę. I choć w wierszu brakuje sygnałów odnoszących się do płci podmiotu lirycznego, większość studentów utożsamia osobę mówiącą w wierszu z czarnoskórą autorką. Otwiera to przestrzeń do interesującej dyskusji na temat subwersywnego stosunku poetki do konwencji sonetu; brak tra-

29 Językowy kształt (the verbal text) tego wiersza pozostał niezmieniony od czasu pierwszego wydania. W The Norton Anthology of Poetry wiersz znajduje się na stronie 1479. 


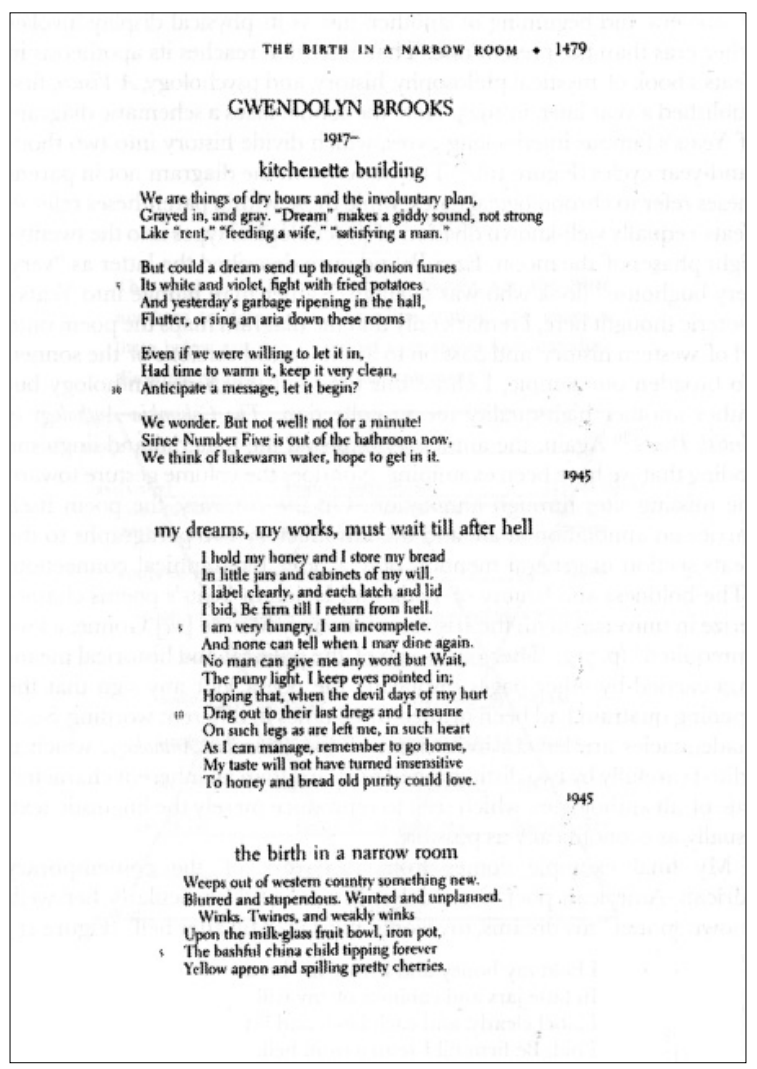

Il. 11. G. Brooks, my dreams, my works, must wait till after hell, druk w The Norton Anthology of Poetry

dycyjnych dla tej formy wierszowej rymów znajduje tu bowiem swoje odbicie w braku tradycyjnej dla sonetu tematyki.

Materialny kształt strony w The Norton Anthology pomija jednak istotne sensy historyczne i polityczne obecne we wcześniejszych materialnych wcieleniach tego wiersza. Najważniejsze z tych sensów ujawniły się na kartach $\mathrm{Se}$ lected Poems, wydanych przez poetkę w 1963 roku $^{30}$. Interesujący nas utwór jest tam trzecim z dwunastu sonetów z cyklu zatytułowanego Gay Chaps at the Bar, którego tematem są doświadczenia czarnoskórych żołnierzy podczas II wojny światowej. Kontekst wojenny wyłania się przede wszystkim z treści, a nawet samych tytułów wierszy (najwyraźniej w przypadku utworu zatytułowanego the white troops had their orders but the Negroes looked like men), ale jest także widoczny w motcie, z którego zaczerpnięty został tytuł zarówno pierwszego wiersza, jak i całego cyklu: ,....and guys I knew in the States, young officers, return from the front crying and trembling. Gay chaps

${ }^{30}$ G. Brooks, Selected Poems, New York 1963, s. 22-23. 
at the bar in Los Angeles, Chicago, New York” (,....chłopcy, których znałem w Ameryce, młodzi oficerowie, po powrocie z frontu - rozstrzęsieni i niemogący opanować płaczu. Weseli chłopcy z barów Los Angeles, Chicago i Nowego Yorku"). Jeśli uwzględnimy materialny kontekst, w jakim wiersz pojawia się na stronie przywołanego tomu, to przedstawione w nim traumatyczne doświadczenie odsłoni swoje konkretne historyczne umocowanie. Okaże się mianowicie, że odnosi się on do doświadczeń wojennych afroamerykańskich żołnierzy. Fragmenty utworu opowiadające o przechowywaniu zapasów miodu „do czasu powrotu z piekła” (,till I return from hell”), wezwanie: „Czekaj” („Wait”), zapowiedź powrotu do codzienności „na takich nogach, jakie mi pozostaną" (,on such legs as are left me”), oraz fraza ,pamiętaj, by wrócić do domu" (,remember to go home”), w swoim pierwotnym znaczeniu odnoszą się do konkretnego, destrukcyjnego doświadczenia wojennego, odsyłają jednak także do codziennego życia Afroamerykanów: segregacja rasowa w armii przywodzi bowiem na myśl inne formy segregacji i rasizmu w amerykańskim społeczeństwie.

Możliwości interpretacyjne, które otwiera cykl Gay Chaps at the Bar w tomie Selected Poems, nie wyczerpują jednak wszystkich znaczeń, jakie da się wyczytać z materialnego kształtu strony. Jeśli sięgniemy do pierwszego wydania tego cyklu w debiutanckiej książce Brooks A Street in Bronzeville (1945), natrafimy na kolejny trop (il. 12) (11 $^{31}$ W tym przypadku cykl poprzedza dedykacja, która została usunięta zarówno z tomu Selected Poems, jak i z przedruków ogłaszanych w antologiach: „dla sierżanta sztabowego Raymonda Brooksa i wszystkich pozostałych żołnierzy". Sierżant sztabowy Raymond Brooks był bratem poetki. Dedykacja nadaje wierszowi my dreams, my works, must wait till after hell wymiar osobisty, spotęgowany jeszcze datowaniem tomu, który ukazał się w roku 1945, gdy wojna wciąż jeszcze trwała. Brooks zadbała o to, aby zarówno cały cykl, jak i poprzedzające go motto oraz dedykacja znalazły się w tomie jej utworów wybranych zatytułowanym Blacks, ogłoszonym po raz pierwszy w 1986 roku przez The David Company w Chicago, a począwszy od piątego wydania z 1991 publikowanym przez wydawnictwo Third World Press. Przejście od dużego „białego” wydawcy do bardziej kontrkulturowego wydawnictwa, nawiązującego nawet swoją nazwą do osób o odmiennym kolorze skóry, ukazuje symboliczną drogę, jaką przebyła poetka - niegdysiejsza stypendystka Fundacji Guggenheima, publikująca w prestiżowym wydawnictwie Harper \& Row - zbliżając się coraz bardziej świadomie do świata Afroamerykanów pod wpływem Ruchu Czarnej Sztuki i konferencji czarnych pisarzy, która odbyła się na Fisk University w Nashville w stanie Tennessee w 1966 roku. Analiza materialnej formy obecności wiersza na stronach wcześniejszych edycji książkowych odsłania osobiste, rasowe i historyczne znaczenia, które zostałyby utracone podczas transferu warstwy słownej pojedynczego sonetu do antologii poezji.

${ }^{31}$ G. Brooks, A Street in Bronzeville, New York 1945, s. 46. 


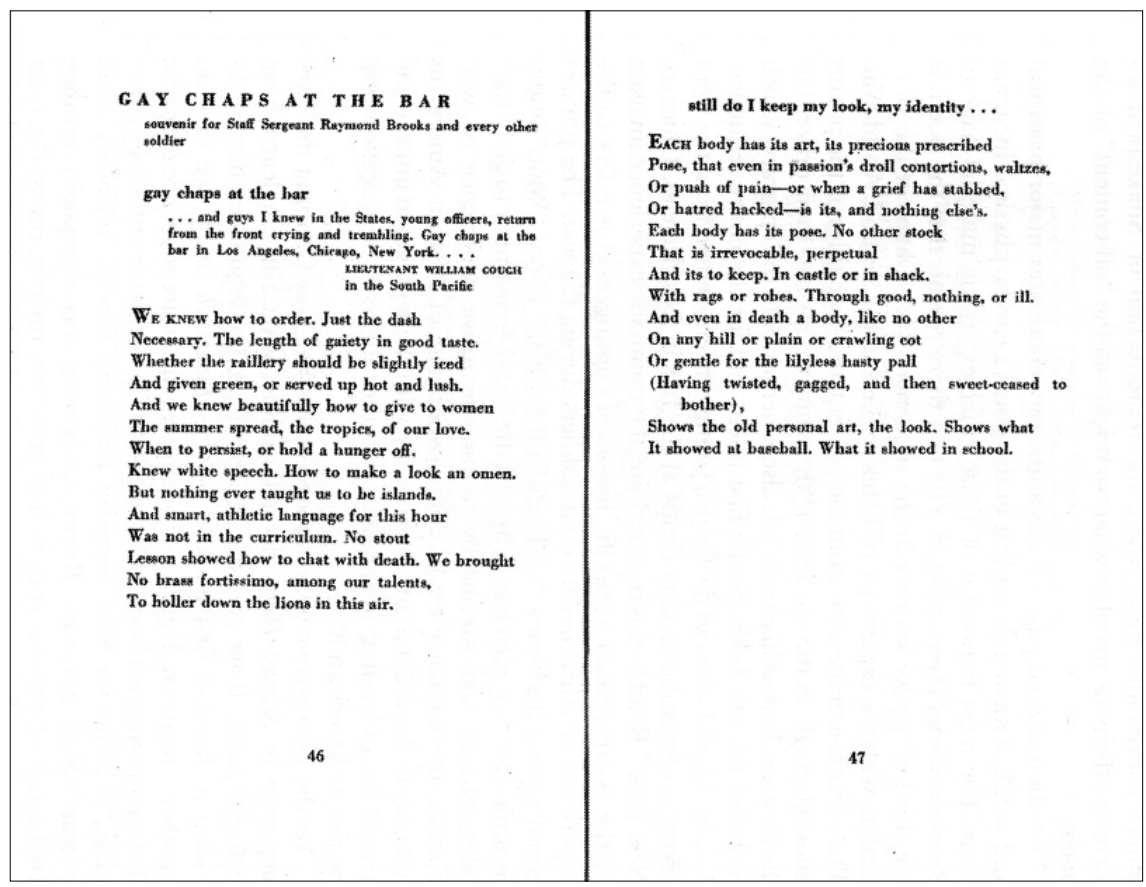

Il. 12. G. Brooks, cykl Gay Chaps at the Bar, druk w książce $A$ Street in Bronzeville, strona $\mathrm{z}$ dedykacją

Jakie wnioski na temat tekstualności możemy więc sformułować na podstawie analizy tych czterech sonetów? Pierwszą i najważniejszą kwestią jest przekonanie, że każda stronica z utrwalonym na niej utworem stanowi konstrukcję, która koduje określone znaczenia, nawet jeśli czyni to kosztem zatarcia innych. W przypadku antologii poetyckich na pierwszy plan wysuwa się znaczenie estetyczne, przesłaniając znaczenia historyczne i polityczne (choć sonet Keatsa uświadamia nam, że także wersje rękopiśmienne często uprzywilejowują to, co estetyczne). Polityka klasowa obecna w On First Looking into Chapman's Homer, rewizjonizm historyczny The New Colossus, kwestie narodowe i kobiece podniesione w Leda and the Swan, a także rasowe podteksty w my dreams my works są łatwo dostrzegalne w pierwszych wydaniach, ale stają się niejasne lub niewidoczne we współczesnych przedrukach. Śledzenie rozmaitych form uobecniania się wiersza na stronie odsłania różnorodne materialne komponenty znaczenia. Te ostatnie przenoszone są zarówno przez kody bibliologiczne, jak i lingwistyczne, dlatego jeśli przedrukowując utwory, skupiamy się wyłącznie na słowach, zacieramy pozostałe znaczenia ${ }^{32}$. Co więcej, opieranie się wyłącznie na współczesnych przedrukach usuwa z pola

32 Przykłady praktycznego zastosowania tych pomysłów na szerokim i zróżnicowanym materiale poetyckim pochodzącym z różnych okresów historycznych znajdzie czytelnik w książce The Iconic Page in Manuscript, Print, and Digital Culture, Ann Arbor 1998. 
widzenia oryginalne, historyczne sensy wierszy i czyni z interpretacji, nawet tych aspirujących do miana politycznych lub historycznych, jedynie rzutowane w przeszłość projekcje naszych współczesnych fałszywych wyobrażeń. Wbrew przekonaniu o istnieniu jednolitego, pojedynczego tekstu, analizując wiersz wydrukowany na stronie, powinniśmy pamiętać także o innych, równie realnych stronach, które mogłyby zastąpić tę, którą mamy przed oczami. Okazuje się, że wiersz istnieje w wielu wersjach, z których co najmniej kilka zasługuje na miano autentycznych lub autorskich, a każda z wersji w jakiś sposób modyfikuje jego znaczenie. Na pytanie, który wiersz jest tym właściwym, możemy odpowiedzieć jedynie słowami Williama Blake’a: „Less than all cannot satisfy the heart of man". Jeżeli Mona Lisa znajduje się w Luwrze, to Król Lear istnieje na niezliczonych stronach rozsianych po całym świecie.

Przekład Joanna Sobesto. Przekład przejrzat i poprawit Tomasz Kunz

\section{Bibliografia}

Abrams M.H., English Romanticism: The Spirit of the Age [w:] Romanticism Reconsidered, red. N. Frye, New York, London 1963, s. 26-72.

Bateson F.W., Essays in Critical Dissent, London 1972.

Bem P., Nowa bibliologia - nowa krytyka. Paradoksy relacji, „Teksty Drugie” 2015, nr 3, s. 31-56.

Benjamin W., Dzieto sztuki $w$ dobie reprodukcji technicznej, przeł. J. Sikorski [w:] idem, Anioł historii. Eseje, szkice, fragmenty, wybór i oprac. H. Orłowski, Poznań 1996, s. 201-239.

Bornstein G., Beyond Words: Reviewing Jerome J. McGann, „, The Textual Condition” and „Black Riders: The Visible Language of Modernism”, „Text” 1995, vol. 8, s. 387-396.

Bornstein G., What is the Text of a Poem by Yeats? [w:] Palimpsest. Editorial Theory in the Humanities, red. G. Bornstein, R. Williams, Ann Arbour 1993, s. 167-193.

Brooks G., A Street in Bronzeville, New York 1945.

Brooks G., Selected Poems, New York 1963.

Cameron S., Choosing Not Choosing: Dickinson's Fascicles, Chicago-London 1992.

Cybulski Ł., Krytyka tekstu i teoria dzieła. Jerome McGann wobec anglo-amerykańskiej tradycji edytorstwa naukowego, „Teksty Drugie” 2014, nr 2, s. 21-48.

Handlin O., The Statue of Liberty, New York 1977.

H.D. [Hilda Doolittle], Collected Poems 1912-1944, red. L.L. Martz, New York 1983.

Holdeman D., Much Labouring: The Texts and Authors of Yeats's First Modernist Books, Ann Arbor 1997.

Keats J., Poems, London 1817.

Keats J., Poetry Manuscripts at Harvard: A Fascimile Edition, red. J. Stillinger, Cambridge, Mass., 1990.

Lewis G., The Yeats Sisters and the Cuala, Dublin 1994.

McGann J.J., Black Riders: The Visible Language of Modernism, Princeton 1993. 
McGann J.J., The Textual Condition, Princeton 1991.

McKenzie D.F., Bibliography and the Sociology of Texts, London 1986.

McLaverty J., The Mode of Existence of Literary Works of Art: The Case of the „Dunciad Variorum”, ,Studies in Bibliography” 1984, vol. 37, s. 82-105.

Miller L., The Dun Emer Later the Cuala Press, Dublin 1973.

Murphy W.M., Family Secrets: William Butler Yeats and his Relatives, Syracuse 1995.

Shillingsburg P., Resisting Texts, Ann Arbor 1997.

Shillingsburg P., Text as Matter, Concept and Action, „Studies in Bibliography” 1991, vol. 44, s. 31-82.

The Columbia Anthology of British Poetry, red. C. Woodring, J. Shapiro, New York 1995.

The Norton Anthology of Poetry, fourth edition, red. M. Ferguson, M.J. Salter, J. Stallworthy, New York 1996.

Trachtenberg M., The Statue of Liberty, New York 1986.

Yeats W.B., A Vision, London 1925.

Yeats W.B., The Cat and the Moon and Certain Poems, Dublin 1924.

Young B.R., Emma Lazarus in Her World, Philadelphia 1995. 